Columbia Law School

Scholarship Archive

1976

\title{
Search and Seizure of the Media: A Statutory, Fourth Amendment and First Amendment Analysis
}

James S. Liebman

Columbia Law School, jliebman@law.columbia.edu

Follow this and additional works at: https://scholarship.law.columbia.edu/faculty_scholarship

Part of the Entertainment, Arts, and Sports Law Commons, First Amendment Commons, and the Fourth Amendment Commons

\section{Recommended Citation}

James S. Liebman, Search and Seizure of the Media: A Statutory, Fourth Amendment and First

Amendment Analysis, 28 STAN. L. REV. 957 (1976).

Available at: https://scholarship.law.columbia.edu/faculty_scholarship/598

This Article is brought to you for free and open access by the Faculty Publications at Scholarship Archive. It has been accepted for inclusion in Faculty Scholarship by an authorized administrator of Scholarship Archive. For more information, please contact scholarshiparchive@law.columbia.edu. 


\section{Search and Seizure of the Media:}

\section{A Statutory, Fourth Amendment and \\ First Amendment Analysis}

On the evening of October Io, I974, police appeared at radio station KPFK-FM in Los Angeles with a warrant authorizing them to search the premises for a New World Liberation Front (NWLF) "communique" that took credit for a recent bombing. The officers conducted an intensive 8-hour search-combing files, listening to tapes, and looking through reporters' notes- finally concluding that the NWLF letter was not at the station. ${ }^{2}$ The KPFK search warrant was one of six that California law enforcement officials have executed at press offices since $1972 .{ }^{3}$ The circumstances surrounding the incident illustrate the rationale behind the recent development of the search technique.

For several years before the KPFK search, the news media had litigated their right not to honor subpoenas from government investigatory bodies

1. See The Reporters Committee for Freedom of the Press, 7 Press Censorshrp Newslettrer [hereinafter cited as PCN] II-r2 (I975); 6 PCN 30 (I975), supra.

2. See 7 PCN II-I2 (I975), 6 PCN 30 (I975), supra note I.

3. See 7 PCN II-I2 (I975), 6 PCN 30 (I975), 5 PCN 33 (I974), 4 PCN 25-26 (I974), 2 PCN I4 (I973), supra note I. The press facilities searched include two affiliates of the Pacifica Radio Network, KPFA-FM in Berkeley and KPFK-FM in Los Angeles, and a self-styled "Third World inner city community station" in San Francisco, KPOO-FM. In addition, police searched the offices of the Los Angeles Star and the Stanford Daily, the former a sexually explicit tabloid, the latter the undergraduate-edited newspaper at Stanford University, and twice searched the Berkeley $B a r b$, an underground newspaper. All these events oecurred in 1974 except the I973 KPFA-FM search and the Stanford Daily search in $197 \mathrm{x}$. Also note the unsuccessful attempt of the Los Angeles Free Press in 1974 to obtain an injunction against an expected police search to recover a "communique" from a radical group claiming responsibility for a bombing. 7 PCN I2 (1975), stupra note I. All of these searches were directed at politically dissident "underground" and college media in order to obtain photographs of or original "communiques" taking responsibility for the allegedly criminal activity of political dissidents. For example, the Stanford Daily warrant named unpublished photographs of a clash between the police and demonstrators protesting minority hiring policies at Stanford University Hospital. The KPFK-FM search warrant directed the seizure of the original "New World Liberation Front Communique." Furthermore, lawyer and CBS reporter Fred Graham asserts that many police actions against the less established press probably go unreported and unlitigated. To illustrate, he cites an unpublicized warrantless search by local police in I969 of the office of the San Diego Street Journal. Graham explains the all-day search which left the office in shambles as in retaliation for the paper's criticism of certain local banking interests. Graham, Background Paper, in TwEnTIETH CENTURY Fund, TAsK Force on the Government aNd the Press, Report: Press FREEDOMS UNDER PrEssURe IO4 (1972). Although one court has ruled that media searches (in fact any search of premises not occupied by a criminal suspect) are unconstitutional absent a showing that a subpoena would be impractical, see Stanford Daily v. Zurcher, 353 F. Supp. I24 (N.D. Cal. 1972), appeal docketed, No. 74-3212, 9th Cir., Nov. 20, 1974, noted in 86 HARv. L. REv. I3I7 (1973) and I9 WAYNE ST. L. REv. I653 (I973), California police have ignored the holding of that case in the six subsequent searches noted supra. 
and courts. They premised claims of immunity from subpoenas on the first amendment protection of newsgathering and on strengthened shield laws for which they had lobbied. Indeed, when KPFK received the communique from the NWLF, the station was in the process of litigating its previous refusal to respect two subpoenas that sought production of communications from other radical groups. ${ }^{5}$ Reiterating the station's policy of not honoring subpoenas prior to judicial challenge, station manager Will Lewis aired the contents of the NWLF letter and offered typed copies of it to press and police, but refused to surrender the original. ${ }^{6}$ Confident that a subpoena would mean months of litigation, even if the courts eventually denied Lewis' statutory and constitutional claims, the police resorted to the ex parte search warrant process, allowing them to seize the evidence immediately, if found, and litigate later, if necessary. ${ }^{7}$

This technique enabled the police more efficiently to vindicate the government's interests ${ }^{8}$ in the investigation and prosecution of crime as well as its broader interest in a judicial dispute-solving mechanism capable of securing relevant information for the benefit of litigants generally-be they the government, criminal defendants or civil litigants. There is reason to expect that the modern trend toward more protective subpoena legislation ${ }^{9}$ and a continued press willingness ${ }^{10}$-albeit with varying success ${ }^{11}$ - to advance constitutional claims of immunity to subpoenas will encourage increasing police resort to the media search warrant ${ }^{12}$ in support of those governmental goals.

While compatible with governmental interests in acquiring information

4. See, e.g., Branzburg v. Hayes, 408 U.S. 665 (I972); Branzburg v. Pound, 46r S.W.2d 345 (Ky. I970).

5. See In re Lewis, 501 F.2d 418 (9th Cir. 1974), cert. denied, 420 U.S. 913 (1975).

6. See 7 PCN II-I2 (1975), 6 PCN 30 (I975), supra note I.

7. California law enforcement officials admittedly developed the search technique to enable rapid acquisition of information relating to criminal activity from uncooperative journalists. Brief for Appellant at 25-28, Stanford Daily v. Zurcher, 353 F. Supp. I24 (N.D. Cal. I972), appeal docketed, No. 74-3212, 9th Cir., Nov. 20, 1974. More pointedly, The Reporters Committee for Freedom of the Press, 6 PCN 30 (I975), supra note I, argues that the California police have used the search procedure to avoid the increasing protectiveness of journalists' shield laws.

8. These interests are discussed more fully at notes 96-104 infra and accompanying text.

9. See note $4 \mathrm{I}$ infra and accompanying text.

Io. See, e.g., In re Bensky, Misc. 75-I8-OJC (N.D. Cal., filed April I4, 1975).

II. Compare id. and Baker v. F \& F Investment, 470 F.2d 778 (2d Cir. I972), cert. denied, 409 U.S. 966 (I973), with Branzburg v. Hayes, 408 U.S. 665 (I972).

12. Most third party searches require search warrants since none of the exceptions to the warrant requirement will apply in that situation. See note 202 infra and accompanying text. Consequently this Note will only discuss warranted searches. In addition, the Note will not focus on the judicial forum in which searches are most often challenged, i.e., the trial of the person implicated by the seized evidence. Nor does it focus on the availability of suppression and exclusion remedies, since the criminal defendant usually does not have standing to challenge a third party search. See note I80 stspra and accompanying text. Instead, this Note's attention is on fora in which one not facing criminal trial may challenge past, and prevent future, uses of the offending investigatory technique. 
about wrongdoing, media searches collide with important interests of journalists and their audiences. ${ }^{13}$ This collision is also illustrated by the KPFK incident. By exposing reporters' notes, files, and tapes to police scrutiny, the KPFK search had the potential to duplicate the harmful effects on the obtaining of information from confidential sources that underlie constitutional and statutory claims of press protection from subpoenas. ${ }^{14}$

By affording several police officers access to all parts of the station's cramped quarters for 8 hours, the search also disrupted the physical operation of the press facility. Moreover, the search warrant authorized police intrusion on KPFK's private premises, and because those premises were occupied by persons not implicated in the crime under investigation, arguably they were surrounded by greater expectations of privacy from government incursion..$^{\mathbf{1 5}}$ Media searches, then, lie at the crossroads of crucial first and fourth amendment interests. ${ }^{16}$ This Note surveys that vital intersection, ${ }^{17}$ through which also pass important societal interests in criminal investigation and judicial acquisition of knowledge, generally. The analysis turns in Part II to a consideration of the best constitutional accommodation of the colliding interests and in Part III concludes with a discussion of several alternative constitutional standards that would restrict or prohibit press searches. But before undertaking a difficult constitutional balancing of competing interests, the Note examines the state shield laws. Legislators have already completed the balancing of relevant interests in drafting these statutes, leaving only the question - considered in Part I-of their application to searches and seizures.

13. These interests are discussed more fully at notes $80-95$ infra and accompanying text.

I4. On the effects of subpoenas on newsgathering, see generally V. BLAsI, Press Subpoenas: An EMPIRICAL and Legai ANAL YSIs (1972).

15. In fact, the only judge yet to hear a constitutional challenge to a search warrant of a press office, see Stanford Daily v. Zurcher, 353 F. Supp. I24 (N.D. Cal. 1972), appeal docketed, No. 743212, gth Cir., Nov. 20, 1974, held that nonsuspects or "third parties" deserve greater protection from searches than suspects. See notes 217-34 supra and accompanying text.

16. In the "pantheon" of constitutional freedoms, first amendment interests have traditionally been accorded a "preferred position." Baker v. F \& F Investment, 470 F.2d 778, 783 (2d Cir. 1972), cert. denied, 409 U.S. 966 (I973); see Kovacs v. Cooper, 336 U.S. 77, 88 (r949). Recently, though, Professor Amsterdam argued powerfully for a similar emphasis on the public's interest in freedom from government intrusion, reflected in the fourth amendment. Amsterdam, Perspectives on the Foutht/ Amendment, $58 \mathrm{MrNN}$. L. Rev. 349, 377-78 (1974). Characterizing speech activity as a "small albeit precious part of the lives of most citizens," he pointed out that even its fullest protection leaves the police almost entirely "unfettered to deal as they please with most of us most of the time." Id at $377-78$. Actually, a nearly identical historical process culminated in the inclusion of both the first and fourth amendments in the Bill of Rights. See N. LAsson, THE HIstory and Developasent of the Fourth Amendment to the United States Constitution 24-25 (1970); L. Levy, Legacy of Suppression, Freedom of Speech and Press in EarLy AMrenican Historx Io-r3 ( 1960$)$. See also note $\mathrm{r}_{3}$ infra and accompanying text.

17. First and fourth amendment issues also have surfaced recently in police searches for and seizure of allegedly pornographic materials illegally held by the media. See note 244 infra. This Note, however, deals only with situations in which the press itself is not implicated in the criminal activity triggering the search. 


\section{The Reporter's Statutory Shield: Protection from Search AND SEIZURE}

\section{A. The Statutory Approach}

In Branzburg v. Hayes, ${ }^{18}$ the Supreme Court rejected broad constitutional insulation of the press from subpoenas and suggested that protection should come instead from state shield laws. ${ }^{10}$ In the wake of Branzburg, courts have developed only tentative and qualified constitutional protections, while many state legislatures have provided more nearly absolute statutory immunity from media subpoenas. ${ }^{20}$ Statutes in over half of the states afford some protection to the journalist, typically using a testimonial privilege format that relieves the journalist from compulsory testimony about a source of information. ${ }^{21}$ About half of the statutes qualify that privilege with balancing standards of varying strictness or deny it in libel cases. ${ }^{22}$ The modern trend expands the testimonial protection to the information

ร8. 408 U.S. 665 (1972).

19. Id. at 706: "There is also merit in leaving state legislatures free, within First Amendment limits, to fashion their own standards in light of the conditions and problems with respect to the relations between law enforcement officials and press in their own areas." Despairing of finding much press protection from subpoenas in state shield laws, commentators usually advocate a more uniform and absolute constitutional privilege. Compare 5I N.C.L. REv. 1550, I555-56 (I973), with Comment, Newsmen's Privilege Two Years After Branzburg v. Hayes: The First Amendment in Jeopardy, 49 TuL. L. REv. 4I7, 436-38 (I975).

20. The most current comparative analysis of state reporters' shield laws, discussing all but one of the laws, can be found in Comment, supra note ig. The newest shield law, OKLA. Stat. ANN. tit. I2, $\$ 385.1-3$ (Supp. 1975), brings to 26 the number of states with shield laws, an increase of ro since 1970. Currently no journalists' privilege exists in the federal courts, although the Department of Justice has issued guidelines regulating requests for the issuance of subpoenas by its employees. Department of Justice Order 544-73, 28 C.F.R. $\$ 50.10$ (I975). The guidelines require United States Attorneys, with the approval of the Attorney General, to seek information elsewhere before approaching the press and to use subpoenas only if the public interest in disclosure outweighs its interest in dissemination of news. The failure to adhere to the guidelines is no defense to a subpoena. See In re Horn, 458 F.2d 468, 473 (3d Cir. 1972). However, Attorney General Levi recently told federal prosecutors that he will strictly enforce the regulations. San Francisco Chronicle, Nov. 20, 1975, at 6 , col. I. In addition, for the past few years Congress has been wrestling with various versions of a federal shield law, but none has passed or seems likely to, partially because of a lack of widespread media support for any one bill. See, e.g., H.R. 215, 94th Cong., Ist Sess. (1975); cf. Graham \& Landau, The Federal Shield Law We Need, Colum. JourNalism REv., Mar./Apr. I973, at 26.

$2 x$. See, e.g., Kr. Rev. Stat. Ann. \$ 42x.Ioo (I974): "No person shall be compelled to disclose in any legal proceeding or trial before any court, or before any grand or petit jury, or before the presiding officer of any tribunal, or his agent or agents, or before the General Assembly, or any committee thereof, or before any city or county legislative body, or any committec thereof, or elsewhere, the source of any information procured or obtained by him, and published in a newspaper or by a radio or television broadcasting station by which he is engaged or employed, or with which he is connected."

22. Compare ARr. Stat. ANn. $\$ 43-9 I 7$ (I964) (disclosure not privileged if it relates to information "published or broadcast in bad faith, with malice, and not in the interest of the public welfare"), with ILL. ANN. STAT. ch. $5 \pi \$ 116$ (Supp. 1976) (divestiture of the privilege upon judicial consideration of "the nature of the proceedings, the merits of the claim or defense, the adequacy" of the remedy otherwise available, if any, the relevancy of the source, and the possibility of establishing by other means that which it is alleged the source requested will tend to prove"). The criticism that state statutes provide insufficient protection of first amendment interests because of their qualifications should be discounted in light of the limited scope of many of the qualifications. But see Comment, supra note I9, at 434-38. 
itself. ${ }^{23}$ Most statutes broadly define the proceedings in which or authorities from whom the journalist is protected from compulsory testimony. ${ }^{24}$

The state shield statutes reflect legislative determinations that to one degree or another press interests in newsgathering free of government intrusion should prevail over society's interest in obtaining evidence for use by criminal investigators and the courts. ${ }^{25}$ That determination obviates the need for intricate constitutional balancing of competing interests. In addition, the statutes reflect that determination in clear-cut standards for applying the evidentiary privilege to the press, in contrast to judicial balancing in this area which often creates standards of uncertain application. ${ }^{26}$ When the courts provide such equivocal protection, confidential news sources may feel no more secure in providing information than if there were no protection. ${ }^{2 \pi}$ Consequently, if the statutes apply to searches, they provide the best front-line defense for the press against government demands for information.

Statutes designed to regulate testimony might not suggest themselves as vehicles for controlling police search warrant procedures, ${ }^{28}$ and none of the

23. See Comment, supra note 19, at 431-32. It reports that eight statutes protect information, as well as the source, from disclosure, seven of which were passed in I973. Actually, Ix of the statutes reviewed there included some protection of information as well as sources. See Mrch. STAT. ANN. 28.945(I) (I972); PA. STAT. ANN. tit. 28, \$ 330 (Supp. I975) (as interpreted in In re Taylor, 412 Pa. 32, I93 A.2d I8I (I963)); R.I. GeN. LAWS ANN. \$\$ 9-I9.I-I to 9-I9.1-3 (Supp. I975). Of those, eight were passed in I973; since then two more states have included information within their shield laws' protection. CAL. Evid. Code $\$$ I070 (West I966), as amended, CAL. Evid. CoDE $\$$ I070(c) (West Supp. I976); OKLA. Stat. ANn. tit. I2, 38 5.I-3 (Supp. I975).

24. See, e.g., MnnN. Stat. ANN. $\$ 595.023$ (Supp. 1976) (no mandatory disclosure before "any court, grand jury, agency, department or branch of the state, or any of its political subdivisions or other public body, or by either house of the legislature or any committee, officer, member, or emplayee thercof . . ."). See also Comment, supra note I9, at 433-34.

25. See notes $43-45$ infra and accompanying text.

26. Compare Branzburg v. Hayes, 408 U.S. 665 (I972), with id. at 7ro (Powell, J., concurring), and Baker v. F \& F Investment, 470 F.2d 778, 783 (2d Cir. r972), cert. denied, 409 U.S. 966 (1973).

27. See Murasky, Branzburg and Its Aftermath, 52 TExas L. Rev. 829, 9 I6 (I973). But see Comment, supra note I9, at 436-38. Ms. Murasky levels similar criticism at the statutes because they lack uniformity and thereby provide no guidance to newspersons and their sources as to what is protected. However, lack of uniformity need not destroy certainty. Insofar as reporters know the law of the states in which they work, they should at least know the scope of protection available in that state's courts. See generally Cades, The Power of the Courts to Protect Journalists' Confidential Sources of Information: An Examination of Proposed Shield Legislation, i I HawaIr B.J. 35.44 (I975). The proliferation of shield legislation explains the decided decline in the number and success of government press subpoenas seeking the name of sources of information, a phenomenon that has puzzled some commentators. See Goodale, Subpoenas of News Reporters to Compel Disclosure of Confidential Information: An Analysis of Recent Legal Developments, 49 Los ANGELES B. BuLl. I33, I4I (1974).

28. No appellate court has yet passed upon the applicability of a shield law-or most other testimonial privileges-to the search and seizure of a press office. However, some courts have refused to apply the fifth amendment privilege against self-incrimination to searches and seizures. See $8 \mathrm{~J}$. WIGMORE, EvideNCE $\S 2264$ (MCNaughton rev. I96I). Wigmore supported this position because he felt the privilege should be involed only to relieve the individual of the dilemma between selfpreservation and morally required self-incrimination. A subpoena establishes a "moral responsibility for truthtelling;" an involuntary search does not. Therefore, he argued, the privilege should not apply to the latter. Note, however, that at least two federal circuit courts of appeals have held that the government may not use search and seizure to obtain documents which, if subpoenaed, would be subject to the self-incrimination privilege. Rather than the "moral responsibility" distinction upon 
statutes specifically includes search warrant restrictions. On the other hand, searches of media offices for evidence of crimes not committed by the press are a modern invention, the first one on record occurring in I97x. Police ingenuity in developing such new investigative procedures exceeds legislative ingenuity in predicting their development. Courts traditionally utilize policy and legislative intent, as well as construction of statutory language, to fill the gaps in the legislative imagination of future contingencies. This section of the Note borrows those judicial tools to examine the scope of the shield laws' applicability in the search and seizure context.

\section{B. The Testimonial Shield Applied to Search and Seizure}

Section royo of the California Evidence Code ${ }^{29}$ presents a valuable model for discussing the application of state shield laws to searches and seizures because California officials have pioneered the use of press searches in the face of the statute's emphatically broad protections. Section ro7o immunizes employees of periodicals, press associations, wire services, and the broadcast media from contempt charges based on any journalist's refusal to respond to a subpoena demanding disclosure of unpublished information. ${ }^{30}$ The statute covers all information, including the names of sources, obtained in the process of gathering news for publication. ${ }^{31}$ Finally, section Iojo reflects the modern trend toward protection both of information and

which Wigmore focuses, the opinions in the Seventh and Ninth Circuits have held that the fifth amendment prohibits all compulsory process used to seek production of incriminatory information and have found the prohibited compulsion in both the search and subpoena situations. See Shaffer v. Wilson, 383 F. Supp. 554, 560-62 (D. Colo. I974), aff'd, 523 F.2d I75 (10th Cir. 1975), discussing the disagreement among the circuits on this point. Even if the privilege against self-incrimination does not apply in the search situation, its distinct policy and background distinguish it from other testimonial privileges protecting confidential communications. See C. McCormick, HaNDBook ON THE LAW OF EVIDENCE \$ 140, at 298-99 (2d ed. I972).

29. CAL. Evid. CODE $§$ rojo (West Supp. I976). Section rojo reads as follows: “(a) A publisher, editor, reporter, or other person connected with or employed upon a newspaper, magazine, or other periodical publication, or by a press association or wire service, or any person who has been so connected or employed, cannot be adjudged in contempt by a judicial, legislative, administrative body, or any other body having the power to issue subpoenas, for refusing to diselose, in any proceeding as defined in Section 90x, the source of any information procured while so connected or employed for publication in a newspaper, magazine or other periodical publication, or for refusing to disclose any unpublished information obtained or prepared in gathering, receiving or processing of information for communication to the public.

“(b) Nor can a radio or television news reporter or other person connected with or employed by a radio or television station, or any person who has been so connected or employed, be so adjudged in contempt for refusing to disclose the source of any information procured while so connected or employed for news or news commentary purposes on radio or television, or for refusing to disclose any unpublished information obtained or prepared in gathering, receiving or processing of information for communication to the public.

"(c) As used in this section, 'unpublished information' includes information not disseminated to the public by the person from whom disclosure is sought, whether or not related information has been disserninated and includes, but is not limited to, all notes, outtakes, photographs, tapes or other data of whatever sort not itself disseminated to the public through a medium of communication, whether or not published information based upon or related to such material has been disseminated." 30. Id.

31. Id. 
sources, ${ }^{32}$ and its successive amendments provide a clear exposition of the legislature's intent. ${ }^{33}$

\section{Mechanical application.}

Facially, section royo seems to cover the search situation. The statute applies if contempt citations might issue from one of several bodies with subpoena powers when a member of the press refuses to disclose information in certain proceedings. Evidence Code section goI defines those proceedings as an "action, hearing, investigation, inquest or inquiry (whether conducted by a court, administrative agency, hearing officer, arbitrator, legislative body, or other person authorized by law) in which, pursuant to law, testimony can be compelled to be given." ${ }^{34}$ All the major elements -enforcement by contempt citation, issuance by agencies with subpoena power, use in particular proceedings-appear analogously in the search and seizure context. The penalty for resisting the execution of a search warrant is a criminal contempt citation. ${ }^{35}$ A magistrate with the power to issue search warrants also has subpoena powers. ${ }^{36}$ Furthermore, successfully barring the door to a search is a refusal to disclose information in an investigation authorized by law.

Most shield statutes go beyond immunizing the reporter from contempt and protect him from compulsory disclosures at the behest of enumerated officials or investigatory bodies. ${ }^{37}$ Under a mechanistic interpretation, these statutes forbid the police-acting either as statutorily enumerated officials or as their agents-from compelling journalists to disclose information.

\section{Policy and legislative intent.}

The mechanical fit of searches in the language of the shield laws is no accident. While generally written with subpoenas in mind, the statutes reflect legislators' intent to enact a policy protecting the press from government investigatory interference.

32. Id.; see Comment, supra note 19, at 434.

33. See notes 38-42 infra and accompanying text for a discussion of the provision's history. While among the more protective shield laws, $\$$ yo7o is not totally unqualified. The California provision, like N.Y. Crv. Righrs LAw $\$ 79-$ h (McKinney Supp. 1975), but unlike most other shield legislation, is less protective in that it is not a testimonial privilege but rather an immunity from contempt. This distinction has consequences for the journalist-litigant who faces other sanctions than contempt, e.g., a default judgment in a libel suit for refusing to testify. Cf. Bramson v. Wilkerson, 3 Cal. Disc. Proc. 72 (Super. Ct. 1962). In addition, the bar to contempt does not apply in a federal diversity case, unlike true privileges. FED. R. Evm. 501; see Apicella v. MeNeil Laboratories, Inc., 66 F.R.D. 78,84 (E.D.N.Y. 1975 ).

34. CaI. EvD. CODE $\$ 901$ (West 1970).

35. See CaL. Penal Code $\$ \$$ I66(4-5), 724 (West I970).

36. See CAL. CodE Crv. PRo. $\$ \$$ Ig86(I), I986(3), 2093 (West r955) (defining the purposes of subpoenas and judicial officers who may issue them); CAI. PENAL CODE $\$ \$ 808,1523$ (West I970) (identifying judicial officers who may issue search warrants).

37. By far the most common language provides that the reporter may not "be compelled to testify or disclose" certain information. See, e.g., ANuz. REv. STAT. ANN. \$ 12-2237 (Supp. 1975). 
In I964, the California Law Revision Commission undertook a study of the predecessor ${ }^{38}$ of section royo. The Commission concluded that the provision afforded "a carte blanche grant of an absolute and unqualified immunity to newsmen to refuse to disclose the source of any information procured for and used in the protected news media."30 The Commission proposed that the absoluteness of the privilege should be tempered by allowing the courts some discretion to deny it. ${ }^{40}$ Instead, however, the California lawmakers since 1964 thrice have increased the statute's protection of the press, extending the range of journalists, proceedings, and information to which it applies. ${ }^{41}$ More than before, the section now reflects what the California Law Revision Commission in 1964 called "a legislative determination that the public interest is best served by nondisclosure in every situation." 42

In a long preamble to its shield statute, ${ }^{43}$ the Nebraska legislature ex-

38. CaL. Code Crv. Pro. $\$$ I88I(6) (West I955), as recodified and amended, CaL. Evm. Code $\S$ I070 (West I974).

39. Cal. Law Rev. Comm'n, 6 Reports, Recommendations, and Studies 484 (1964).

40. Id. at 505 .

4I. In I97I, the provision was widened to include former as well as current journalists. This was done in direct response to a court's threatened overly narrow interpretation. A former newspaper reporter was adjudged in contempt for refusing to disclose to a court the source of an information leak during the Manson trial. At the time, $\S$ I070 applied only to "journalists employed upon a newspaper." While deciding the case against the ex-reporter on other grounds, the court opined that "[s] ection I070 read strictly does not include petitioner within the scope of its immunity." Farr v. Superior Court, 22 Cal. App. 3d 60, 69, 99 Cal. Rptr. 342, 347 (2d Dist. r97r), cert. denied, 409 U.S. IOII (I972); the same year the legislature rejected that strict interpretation. A bill was passed extending $\S$ Io7o's protection to information procured by "any person who has been ... connected [with] or employed" by the press. CAL. Evid. CoDE $\$$ IOzo (West I972). The provision was widened again in 1972 by adding immunity from subpoena by "any other body having the power to issue subpoenas." CAI. Evid. CODE $§ 1070$ (West 1973). The legislature apparently assumed that the successive revisions had made the privilege absolute in all local and state legislative, investigative and administrative proceedings. In 1974 the California Legislature once again amended $\$$ I070 against the backdrop of the minute examination of shield laws occurring in the courts and the literature in the early 1970s. In 1973, for example, a commentator published an extensive analysis of the California shield law. See Comment, Newsman's Privilege: A Survey of the Law in California, 4 PAC. L.J. 880 (I973). The author found the law "virtually an absolute privilege" except for some ambiguous language susceptible to probably erroneous narrow judicial interpretation. Id. at gor. The author suggested three such areas: whether "source" included the news itself as well as the informer, whether magazine employees were protected, and whether prior dissemination of part of the information gathered waived a privilege as to the rest. Id. These questions and others had also been raised concerning $\S$ I070 and similar shield laws in cases around the country. On the interpretation of "source," compare In re Taylor, 4I2 Pa. 32, I93 A.2d I8I (I963) ("source" includes "information"), with State v. Sheridan, $248 \mathrm{Md} .320,236 \mathrm{A.2d} \mathrm{I8} \mathrm{(1967)} \mathrm{(criticizing} \mathrm{Taylor} \mathrm{in} \mathrm{dicta),} \mathrm{and} \mathrm{Forest} \mathrm{Hills}$ Util. Co. v. City of Heath, 302 N.E.2d 593 (Ohio Ct. C.P. r973); on the press publications covered, see Application of Cepeda, 233 F. Supp. 465 (S.D.N.Y. I964) (diversity suit interpreting the California statute at that time not to include magazine reporters within "newspaper reporter"); on the waiver question, see People v. Wolf, 39 App. Div. 2d 864, 333 N.Y.S.2d 299 (Sup. Ct. App. Div. 1972) (publication of an edited article waives a privilege as to the unedited version). The California legislators' 1974 amendment of $\S$ I070 expressed a clear opinion as to how they meant to resolve the ambiguity which these judges and scholars had discovered in shield laws. They filled every imagined loophole in the protections of the press so that the ingenuity of judges and government investigative badies would no longer defeat their protective intent.

42. 6 Reports, supra note 39, at 502. See Comment, Criminal Procedure; Netusmen's Immunity from Contempt, 4 PAc. L.J., 387,388 (1973).

43. NEB. Stat. ANN. \$ 20-I 44 (I974): "The Legislature finds: ( $\mathrm{r}$ ) That the policy of the State of Nebraska is to insure the free flow of news and other information to the public, and that those who gather, write, or edit information for the public or disseminate information to the public 
plained what public interests are best served by nondisclosure of press information in government investigations. The legislators noted that forcing journalists to disclose information or its source "inhibits the free flow of information to the public." "The preamble therefore defines it as Nebraska policy to encourage newsgathering and dissemination free of direct or indirect restraint "imposed by governmental process."

Because both the search warrant and the subpoena are "governmental process" compelling disclosure of information before an investigative agency, both are equally condemned by the shield laws' policy. Police scrutiny of files containing information provided by confidential sources inhibits those sources and thus the "free flow of information to the public" no less than production of those files before a secret grand jury, to which the statutes clearly apply. ${ }^{40}$ Moreover, because the history and language of many of the statutes, like California's, reflect a legislative resolution to protect all journalists from compulsory disclosure at the behest of all governmental officials, ${ }^{47}$ the statutes should apply to police executing search warrants against the media as well as to prosecutors, grand juries, judges, and legislators issuing subpoenas to them.

A distinguished judicial tradition favors a narrow interpretation of all testimonial privileges, including shield statutes, ${ }^{48}$ because they violate the maxim that "the public has a right to every man's evidence." ${ }^{49}$ However, legislators apply that policy to benefit government agencies by according them the subpoena power. ${ }^{50}$ Lawmakers, however, have traditionally withheld the subpoena power from most executive law enforcement officials and all police officers, deeming them incompetent to utilize the power judiciously. ${ }^{51}$ Shield statutes should not be read to permit the police to procure infor-

may perform these vital functions only in a free and unfettered atmosphere; (2) That such persons shall not be inhibited, directly or indirectly, by governmental restraint or sanction imposed by governmental process, but rather that they shall be encouraged to gather, write, edit, or disseminate news or other information vigorously so that the public may be fully informed; (3) That compelling such persons to disclose a source of information or disclose unpublished information is contrary to the public interest and inhibits the free flow of information to the public; (4) That there is an urgent need to provide effective measures to halt and prevent this inhibition ....."

44. Id.

45. Id.

46. See notes $192-99$ infro and accompanying text, arguing that the search procedure actually more drastically inhibits confidential sources than the subpoena.

47. The California provision describes the governmental agencies before which a newsperson may refuse to testify no more broadly than most other states' statutes. See, e.g., note 24 stupra. Some statutes actually apply more explicitly than California's to the police. See, e.g., N.M. STAT. ANN. $\S 20-1-12 . I(B)(I)$ (Supp. I975) ("includes any proceeding or investigation before, or by, any legislative, judicial, executive or administrative body or person").

48. See $8 \mathrm{~J}$. Wigmore, supra note 28 , at $\$ 2192$.

49. Id., paraphrasing Sir Francis Bacon in the Countess of Shrewsbury's Trial, 2 Howell's St. Trials 769, 778 (I6r2). See C. McCoRMrCR, supra note 28 , at $\$ 77$.

50. This is Wigmore's conclusion. $8 \mathrm{~J}$. WIGMORE, supra note 28 , at $\$ \$ 2199$ (i-ii), 2I94(a), 2200; accord, People v. Gonzales, 20 Cal. 2d I65, I7I, I24 P. 2 d 44, 47 (I942).

5I. See C. McCosmick, supra note 28 , $\$ 137$, at 290 , indicating that the general tendency is not to give law enforcement officials the subpoena power. But note Delaware's statutory grant to the 
mation when they deny that privilege to other agencies that are usually more favored in evidence gathering. ${ }^{52}$ In fact, the traditionally narrow reading of these statutes, premised on their contravention of the important public policy favoring provision of evidence before certain agencies, is inappropriate in the search context, ${ }^{53}$ since that policy has never favored police evidence procurement. ${ }^{54}$

Attorney General of subpoena powers coextensive with those constitutionally allowed the grand jury. See In re Hawkins, 50 Del. 6r, I23 A.2d II3 (1956). Note, however, that state's requirement that such subpoenas, to be valid, must not extend the "statutory and historical scope" of the subpoena power to "transform its original grand jury function into a police instrumentality." In re MicGowen, 303 A.2d 645, 647 (Del. 1973).

52. The exclusionary rule, see Mapp v. Ohio, 367 U.S. 643 (I96I), does keep some illegally seized information from the courts that the police may obtain. But see United States v. Calandra, 4I 4 U.S. 338 (1974) which allows grand juries to utilize such evidence. Nonetheless, all seizures to which the exclusionary rule applies are illegal; the law does not authorize their use by any government officials. Modern criticism, in fact, condemns the suppression rule because its exclusionary impact falls on the courts, rather than the police, despite society's traditional desire to have the courts utilize all relevant information available to them. See generally Burger, Who Will Watch the Watchmen?, I4 AM. U.L. REv. I (I964); Schrock \& Welch, UP From Calandra: The Exclusionary Rule as a Constitutional Requirement, 59 MinN. L. Rev. 25I, 289-95 (1974). Thus even given the vagaries of the exclusionary rule, society nowhere authorizes greater police access to information than courts, grand juries and legislators have. And by giving the police less access to information than other agencies, since police are not accorded the subpoena power, the law belies any claim that society at times has a greater interest in police access than it does in agencies' access.

53. Both the policy behind the shield laws and their passage by legislatures in the face of the traditionally strong judicial policy against privileges, promotes expansive interpretation in all situations. Accord, In re Taylor, 4I2, Pa. 32, 40, I93 A.2d x8I, I85-86 (I963). See also C. McCormck, supra note $28, \S 118$, at 253 , arguing in favor of a testimonial privilege (in this case, against selfincrimination) to cushion the impact of government investigations on free expression. The "strong public policy in favor of the protection of certain communications" leads courts to apply evidentiary privileges where conflict of laws rules would otherwise not permit. Application of Cepeda, 233 F. Supp. 465 , 47 I (S.D.N.Y. I964) (applying California's shield law to a deposition taken in New York, though in a suit filed in the former state); see Baker v. F \& F Investment, 470 F.2d 778, 782 (2d Cir. 1972), cert. denied, 4II U.S. 966 (I973) (federal question proceeding in which the shield laws in the relevant states did not control but were accorded persuasive weight by Chief Judge Kaufman as expressions of "a paramount public interest in the maintenance of a vigorous, aggressive and independent press capable of participating in robust, unfettered debate over controversial matters ...."). Insofar as the modern trend has been toward extension of the statutes and especially insofar as some of those extensions have been direct responses to judicial and academic attempts to read the statutes narrowly, the legislative history of the statutes argues for broad interpretation. Section Iojo's legislative history, consistent with the provisos in the previous sentence, is discussed in note $4 \mathrm{I}$ stipra. See also, for example, changes in New Jersey's law, N.J. STAT. ANN. $\$ 2 A: 84 A-2 I$ (I976), formerly N.J. Stat, ANN. $\$ 2 A: 8 \mathrm{r}-10$, which extended protection in I960 to the "means" by which, as well as the source from whom, the information was obtained, clearing up an ambiguity noted in State $v$. Donovan, I29 N.J.L. 478, 486-87, 30 A.2d 421, 426 (r943). Similarly, amendments to the New York law, N.Y. Crv. Rigrrs LAw $\$ 79-\mathrm{h}(8)$ (b) (McKinney Supp. r970), explicitly forbade grand juries from seeking contempt citations against journalists for refusing to disclose information-protection only implicitly within the unamended statute. Some of the newer laws enacted in the wake of the national controversy over the rights of reporters with respect to government demands for evidence include strong statements of purpose or intent concerning many of the controversial areas of interpretation. See, e.g., N.M. STAT. ANN. $\$ 20-I-I 2.1$ (A) (Supp. I975); note 43 stlpra.

54. A contrary reading would allow seizure of tangible items that could thereafter not properly be entered into evidence absent the authentication that the journalist, pursuant to the shield, may refuse to make. An interpretation of the shield law not to limit press searches would allow the police, for example, to seize a "Symbionese Liberation Army" communique and find fingerprints on it leading to a suspect, all of which a grand jury, not bound by most rules of evidence, could use to indict. But the linkage of the document to the suspect at the subsequent trial may be impossible without authentication by the searched newsperson who could refuse to testify by involing a shield law. See Transcript Rulings Before Judge Avakian, at 34 , In re Death of Marcus Foster (Super. Ct. Dep't I, March 28, r974) (involving a case similar to this hypothetical in which a California court applied California's shield law to prevent the reporter from having to testify and barred the evidence). It is unlikely that the Legislature would authorize the police to obtain evidence that no other body could make use of in the prosecution of crime. See note 52 sispra. 
Clearly, journalists seeking protection from the execution of an expected search warrant should first attempt to interpose the statutory shield between themselves and the police. The language and policy of the statutes are broad enough to provide the press with some shelter from searches. However, judicial extension of the statutes to search warrants only partially protects journalists from searches. The next section discusses the breaches in that protective shield.

\section{Difficulties in the Application of Shield Laws to the Search Context}

\section{Limitations in jurisdictional applicability.}

Shield laws apply in only 26 states. ${ }^{55}$ With the exception of federal prosecutors, bound by nonjudicially cognizable Justice Department guidelines, ${ }^{\text {ti }}$ federal officials are free to procure evidence from the media to the same extent they can from other citizens. While the shield laws do apply in federal diversity cases, ${ }^{57}$ they do not bind federal courts exercising federal question jurisdiction. ${ }^{\text {ss }}$ To the extent that a confidential source's information might relate to activity that in turn might attract scrutiny from federal officials, or from state officials unrestrained by one of the 26 laws, the source will remain inhibited, despite the protection the statutes may afford in other situations. Certainly the alleged multistate activities-including such federal offenses as bank robbery ${ }^{59}$ and kidnapping ${ }^{60}$-of underground groups, whose communications have traditionally triggered searches, ${ }^{01}$ will rarely be completely immunized from governmental scrutiny by the 26 statutes.

\section{Unprotected journalists.}

Even if the statutes assure confidential sources that their information will avoid the reach of government officials who are unconstrained by shield statutes, sources still may be afraid to pass the information to reporters. In addition to the statutes' uncertain application to searches in general, and their occasional use of broad balancing qualifications, ${ }^{{ }^{2} 2}$ some of them also specifically exclude from protection ${ }^{63}$ certain journalists, ${ }^{64}$ and certain kinds of information. ${ }^{65}$ Similarly, some courts interpret the statutes to

55. See note 20 supra.

56. See id.

57. See FED. R. EvID. 501.

58. See In re Lewis, 5or F.2d 4 I 8 (gth Cir. 1974), cert. denied, 420 U.S. 9 I3 (I975).

59. I8 U.S.C.A. \$2113 (Supp. 1975).

60. Id. $\$$ I20I.

6r. See note 3 supra.

62. See note 22 supra and accompanying text.

63. See generally Comment, supra note I9, at 429-36.

64. Some statutes potentially exclude "underground" papers by requiring that the press meet certain circulation and publication date requirements to be protected. See, e.g., IND. STAT. ANN. $\$ 34-3-$ 5-I (Supp. 1975).

65. The typical situation in which the police have used the search procedure concerns "communiques" from dissident political groups. See note 3 supra and accompanying text. The statutes 
require an explicit understanding of confidentiality between reporter and source $^{68}$-an especially troublesome requirement with respect to "communiques" anonymously sent to press offices with the expectation of publication or broadcast. A few of the statutes also hold that partial publication or broadcast waives the privilege as to unpublicized portions of confidential communications. ${ }^{67}$ It should be noted, however, that broadly drawn statutes -including, for example, section ro7o-may avoid all of these pitfalls. ${ }^{\text {"8 }}$

are about evenly split as to whether only "sources" or all information is protected from disclosure. See note 23 supra and accompanying text. Under the former type of provision, the argument that the "communique" fits within the protected "source" would focus on the fact that the police want the document for fingerprint, voice, background noise, and/or typewriter analysis, all leading to the identification of its source. See, e.g., In re Bensky, Misc. 75-18-0JC (N.D. Cal., filed April 15, 1975). The courts generally take a liberal view in their interpretation of "source" to deny the government access to information that would "directly" or "indirectly ... identify or help to identify the source of the communications," or have "any chilling effect on sources of information from the disclosure of this kind ...." Transcript Rulings Before Judge Avakian, at 42, In re Death of Marcus Foster (Super. Ct. Dep't I, March 28, I974); see Forest Hills Util. Co. v. Heath, 302 N.E.2d 593, 597 (Ohio Ct. C.P. I973).

66. New York courts in particular have insisted that the protected information must have been "imparted to the reporter under a cloak of confidentiality, i.e., upon an understanding, express or implied, that the information or its sources will not be disclosed. . ." People v. Wolf, 69 Misc. $2 \mathrm{~d} 256,26 \mathrm{r}, 329$ N.Y.S.2d 29r, 297, aff'd, 39 App. Div. 2d 864 (1972). In the "communique" situation discussed supra note 65, one New York court suggested that the anonymity of a letter signed only by the "Weather Underground" belies any confidential relationship between the recipient radio station and the writer. WBAI-FM v. Proskin, 42 App. Div. 2d 5, 344 N.Y.S.2d 393 (r973). The confidentiality requirement seems to come from the traditional but here less applicable requirement that information privileged from disclosure because of a need to protect some professional relationship must have been imparted in confidence. See $8 \mathrm{~J}$. WIGMORE, supra note 28 , at $\$ 2285$. With respect to testimonial privileges generally, the modern trend liberalizes this by requiring only a confidential intent, even if the communication was purloined or eavesdropped and thus not actually confidential. C. MCCorMick, supra note 28, at $\$ 75$. As the dissent in Proskin argued, the fact of anonymity itself clearly manifests to the reporter the communicant's intent not to publicize at least his name and perhaps part of the information. WBAI-FM v. Proskin, 42 App. Div. 2d at 9-IO, 344 N.Y.S.2d at 397 (Cooke, J., dissenting). More broadly, the victims of searches are usually media organizations that have established relationships of trust and confidence with radical organizations, without which the information would not have been sent. For example, consider one searched radio station in San Francisco, KPOO-FM, which announced a station policy not to act as a "police information agency" after the "New World Liberation Front," the source of the "communique" that was listed in the search warrant, demanded that the station not release anything it received from the group. With respect to the journalists' privilege, the modern judicial trend has been to dispense with the requirement of confidentiality entirely, since it has little applicability to the privilege's policy of free flow of information to the public (rather than to a lawyer or doctor, for example). See Branzburg v. Hayes, 408 U.S. 665, 726 n.2 (I972) (Stewart, J., dissenting); Loadholtz v. Fields, 389 F. Supp. 1299, 1302-03 (M.D. Fla. I975); Lightman v. State, 15 Md. App. 713, 724, 294 A.2d I 49, 156 (Ct. Spec. App.), aff d, 266 Md. 550, 295 A.2d 212 (I972), cert. denied, 4 II U.S. 95 I (1973) (explicitly rejecting the Wolf interpretation). But see In re Lewis, 50I F.2d 418,422 (gth Cir. 1974), cert. denied, 420 U.S. 9r3 (r975). Actually the confidentiality requirement in New York, not yet passed upon by the Court of Appeals, has been rejected by two New York lower courts. Compare In re CBS (Sup. Ct. Ontario County, order filed June 25, 1971), and People v. Bonnakemper, 74 Misc. $2 d$ 696, 345 N.Y.S.2d 900 (Rochester City Ct. I973), with In re Dan, 80 Misc. 2d 399, 363 N.Y.S.2d 493 (Sup. Ct. x975). Some statutes include within their protection information clearly not received under an explicit promise of confidentiality. E.g., CAL. Evid. CODE, $\S$ I07o(c) (West Supp. 1976 ).

67. In the "communique" situation, the group so communicating obviously intends that the message, if not the medium, be aired. Under a few statutes, the broadcast or publication of that message may waive the entire privilege. See, e.g., N.J. STAт. ANN. $\$ 2 A: 84 A-2 I$ (West r976), as interpreted in In re Bridge, r20 N.J. Super. 460,295 A.2d 3 (I972), cert. denied, 410 U.S. $99 \mathrm{I}$ (1973).

68. CaL. Evid. Code $\$$ Io70 (West Supp. 1976) requires that the information protected from disclosure be "obtained" by the press. Niggardly judicial interpretation might find this language insufficient to encompass the passive reception of a letter from a radical group. But see WBAI-FM v. Proskin, 42 App. Div. 2d 5, 8, 344 N.Y.S.2d 393, 396 (r973) (Cooke, J., dissenting): "[N]o logical 


\section{The unwieldiness of the shield.}

The most troublesome stage in the application of shield statutes to search warrants occurs after the journalist has overcome the interpretive problems discussed above. Assured that the legislation's shield should protect him, the journalist must find a way to interpose it between himself and law enforcement officials as rapidly as the latter can secure a search warrant and execute it. Because the police obtain warrants in ex parte proceedings from magistrates who may act as quickly as police can prepare affdavits, ${ }^{69}$ the journalist will have difficulty interceding at the procurement stage of the warrant procedure. Very possibly the first notice the journalist will have of the proposed search will be when the police are knocking at his door, warrant in hand. ${ }^{70}$

Should he choose to oppose the warrant the journalist has two unsatisfactory options: immediate forceful resistance, or subsequent remedial litigation. Forceful resistance by journalists is arguably irremedial since the statute's immunization of reporters from legal compulsion, including contempt citations, for choosing nondisclosure removes the normal remedy for resistance to process of court. ${ }^{71}$ Nonetheless, if reporters, confident of the statute's applicability, interpose themselves between their files and the police, they invite the police to exercise their statutory power to brush resisters aside, break down locked doors, and execute the warrant. ${ }^{72}$ Accepting the inevitable-acquiescing in the search and initiating subsequent judicial action -may afford journalists only slightly more protection. Police reliance even on an illegal search warrant issued by a magistrate probably satisfies the "good faith" or "pursuant to duty" defenses that immunize law enforcement officials from tort liability for damages. ${ }^{73}$ And even if the court enjoins further searches and/or declares past ones illegal ${ }^{74}$-in fact, even if re-

distinction can be drawn between affirmatively gathered news and that received passively from other sources." Arguably, the underground press' establishment of contacts with radical groups who then forward information to these media organizations constitutes a process by which information is actively obtained. See note 66 stipra. Some statutes clearly encompass information that was merely "delivered" to the press, e.g., N.J. Stat. ANn. $\$ 2 A: 84 A-2 I$ (1976).

69. The mechanics of the search warrant process from issuance to execution are discussed at notes I68-20x infra and accompanying text.

70. This is not universally so. See, for example, the policy of some California reporters, anticipating searches, to inform police that items subject to searches will not be kept in their press facility's offices. Cf. 6 PCN 30 (1975), supra note I. Note also the unsuccessful attempt of the Los Angeles Free Press to secure an injunction against an expected search warrant. See 7 PCN 12 (1975), supra note I. Note 75 infra discusses this incident in greater detail.

$7 \mathrm{I}$. See notes $34-37$ supra and accompanying text.

72. See, e.g., CAL. PENAL CODE $\$ \$ 723, x_{531}, 5_{532}$ (West r970). These statutes authorize a public officer to raise a posse of "male inhabitants of his county" and if necessary to break down doors to execute the warrant.

73. Given standing rules that deny the benefit of the exclusionary rule to criminal defendants whose property was not searched, the suppression remedy affords no protection to victims of searches who are unimplicated in crime. See note 180 infra and accompanying text for a discussion of the remedies available to nonsuspect victims of illegal searches.

74. While denying injunctive relief following a police search of newspaper offices that it held unconstitutional, one court issued a declaratory judgment concerning the warrant's illegality. See 
porters overcome the good faith defenses and receive monetary relief-the damage precipitated by the search can hardly be undone. Sources whose timidity inspired a desire for confidentiality will receive slight comfort from these remedies awarded long after the police have rifled reporters' files, read their notes, and listened to their tapes.

These caveats, however, need not deter journalists from pursuing statutory remedies. Once the courts-even in after-the-fact proceedings-clearly apply the shield laws to the search situation, reporters can rely on magistrates if not police to heed them. ${ }^{75}$ Judges eschew violence and would endeavor to avoid even the abstract possibility that journalists, immune from legal redress, might try to resist the forceful execution of a warrant. ${ }^{76}$ Moreover, the more clearly unauthorized the search, the less certain the availability of good faith defenses, and the greater the likelihood that police will forego the warrant alternative. ${ }^{77}$

\section{Conclusion: the Applicability of State Shield Laws to the Search Warrant}

The shield laws permit newspersons to reject government demands for news-related information in their possession. State legislatures have balanced the competing interests and in different forms and with various qualifications have deemed certain press interests supreme. Solely with reference to their language, it is probably fair to interpret many of the statutes to afford a freedom from searches and seizures. And their underlying policy to erect a shield between the press and government intrusion should immunize the media from producing evidence at the behest of police executing warrants as well as at the command of other government agencies issuing subpoenas. This conclusion is reinforced by the interpretive environment surrounding the statutes, which calls for their liberal applica-

Stanford Daily v. Zurcher, 353 F. Supp. I24 (1972), appeal docketed, No. 74-3312, 9th Cir., Nov, 20, 1974 .

75. In I974, the Los Angeles Free Press received a communication from the New World Libcration Front taking responsibility for a bombing. Mindful of the Los Angeles Police Department's search of KPFK-FM earlier in the month, see note I supra and accompanying text, the newrspaper sought an injunction against the expected search warrant. The Free Press based its plea on the Stanford Daily case. See note 74 supra; notes 217-34 infra and accompanying texts. The Los Angeles County Superior Court denied the injunction, assuring the media that police and magistrates know and presumably follow the law. See 7 PCN 12 (1975), supra note I, of. Demich, Inc. v. Ferdon, 426 F.2d 643, 646 (9th Cir. r970), vacated and remanded, 401 U.S. 990 (I97I) (unnecessary to enjoin magistrates from issuing illegal warrants). To the extent that a state statute (as opposed to a federal district court's constitutional pronouncement, as in the Stanford Daily case) clearly barred a warrant, the magistrates might be more likely to refuse to authorize one.

76. In a similar situation, one California judge, construing $\S$ rojo to immunize a journalist for contempt for refusing to testify, would not even order the journalist to do so. Transcript Rulings Before Judge Avakian, at 42, In re Death of Marcus Foster (Super. Ct., Dep't I, March 28, I974). The judge stated that he would "not order somebody to answer a question when [he had] no means of enforcing that order." Neither, presumably, would he issue a media search warrant, authorizing violent execution of it, when he has no means of punishing a journalist's successful resistance to it; much less would a court force the journalist to resist in order to invoke that protection.

77. But see note 75 stspra. 
tion to agencies like the police that are not traditionally favored by society with government evidence-gathering powers. However, especially in light of the suspicion that the police have used searches to subvert the statute's policy and because of the need to provide the clearest guidance to magistrates and police, this Note recommends that legislatures remove shield laws' ambiguity by explicitly extending them to searches.

\section{Constitutional Protection of the Press from Search and Seizure: Extending Branzburg's Grand Jury Subpoena Analysis to Police SeArches}

In federal courts and in the states without shield laws, the press must resort to the Constitution for protection from police searches. Even in those states with shield laws, the constitutional argument remains an important second line of protection, underscoring the policies behind the statutes. ${ }^{78}$ This Part will first identify the constitutionally recognized press and governmental interests at stake in official demands for information from the media. It will consider how courts have balanced these interests in the wake of Branzburg v. Hayes, ${ }^{79}$ a case concerning newspersons' constitutional privilege against disclosure of information in the face of grand jury subpoenas. After extending those post-Branzburg formulations to police investigatory intrusions on the press through search warrants, it will conclude that the subpoena and warrant procedures differ substantially in their effect upon press and governmental interests and require a different balancing of those interests in the search and seizure context resulting in greater protection of the press from searches than that constitutionally available in the subpoena context.

\section{A. The Interests Involved in Search and Seizure of the Press}

Although partisans in the press search debate most often characterize the dispute as a simple confrontation between press freedoms and society's need to protect itself from crime, other interests actually complicate the controversy. This section will discuss four interests inevitably involved in the press search controversy whose interrelationship determines the legal limits of media searches.

\section{Press interests.}

Privacy of the press. The fourth amendment's guarantee that the people shall "be secure ... against unreasonable searches and seizures . . ."80

78. State constitutions' free press provisions provide a potentially important third line of protection. See Falk, The State Constitution: A More Than "Adequate" Nonfederal Ground, 6r CaLIF. L. REv. 273 (1973).

79. 408 U.S. 665 (1972).

80. U.S. Const. amend. IV. 
testifies to the framers' recognition that citizens' privacy should be protected against government intrusion. ${ }^{81}$ Members of the press, like participants in other businesses, enjoy constitutionally protected expectations of privacy concerning their private media facilities, as well as their homes. ${ }^{82}$ Journalists also have personal files, memoranda, and numerous compilations of confidential information which they are constitutionally entitled to shelter from governmental intrusion, even if the business institution rather than the individual technically owns the items. ${ }^{83}$

Significantly, searches of the press are typically "third party" searches, that is, neither the journalists nor anyone else on the premises is suspected of criminal activity. One court has suggested that nonsuspects enjoy more potent expectations of privacy than persons implicated in criminal activity. ${ }^{84}$ While the search warrant currently affords the highest level of fourth amendment protection from searches, ${ }^{85}$ its summary and ex parte issuance by a magistrate applying a probable cause standard that is insufficiently sensitive to special privacy interests may inadequately protect greater third party interests in privacy. ${ }^{86}$

It is possible that with careful attention to the interests involved, the fourth amendment alone would solve the third party search problem without recourse to special first amendment interests involved in third party searches of the press. ${ }^{87}$ But this Note argues that the better course is to

8I. The most frequently cited Supreme Court reformulation of the fourth amendment states that "wherever an individual may harbor a reasonable 'expectation of privacy, . . . he is entitled to be free from unreasonable governmental intrusion." Terry v. Ohio, 392 U.S. $x, 9$ (r968), quoting Katz v. United States, 389 U.S. $347,36 \mathrm{I}$ ( 1967 ) (Harlan, J., concurring). For criticism of this standard, see Amsterdam, supra note I6, at 383. Modern constitutional jurisprudence recognizes that governmental interference in intimate matters or private decisions may violate the fourth amendment even if accomplished by means other than unreasonable search and seizure. This line of interpretation of the fourth amendment forms only one aspect of a more general privacy right implicit in the first, third, fourth, fifth and ninth amendments. See, e.g., Griswold v. Connecticut, 38 I U.S. 479, 485 ( 1965 ) (holding unconstitutional laws regulating the use of contraceptives because enforcing them would unduly intrude upon the privacy of the "marital bedroom").

82. See Mancusi v. DeForte, 392 U.S. 364,367 (I968); Katz v. United States, 389 U.S. 347 , 35r-52 ( 1967 ); See v. Seattle, 387 U.S. 54I, 543 (I967).

83. See Mancusi v. DeForte, 392 U.S. $364,366-69$ (r968); See v. Seattle, 387 U.S. 54I, 543 (I 967 ). If incorporated, the press facility also has a protected interest in freedom from unreasonable searches and seizures. See FTC v. American Tobacco Co., 264 U.S. 298 (1924). However a corporation's interest in privacy may not loom so large as an individual's. See United States v. Morton Salt Co., 338 U.S. 632,652 (1950).

84. Stanford Daily v. Zurcher, 353 F. Supp. r24 (N.D. Cal. I972), appeal docketed, No. 743312, 9th Cir., Nov, 20, 1974. The court held that third party searches should only occur after the police have satisfied the magistrate that a subpoena would not suffice. Since the same requirement does not extend to searches of suspects' property, the court implies that persons implicated in crime have lesser constitutionally protected expectations of privacy than unimplicated persons. See notes 2I7-34 infra and accompanying text.

85. See A. Amsterdam, Trial Manual for the Defense of Criminal Cases $§ 229$ (I975). Professor Amsterdam suggests that courts nearly always hold properly warranted searches reasonable under the fourth amendment.

86. This theory is discussed at notes $163-20 x, 2 \times 7-34$ infra and accompanying text.

87. This is essentially the position taken by Judge Peckham in Stanford Daily v. Zurcher, 353 F. Supp. I24, 132-33 (N.D. Cal. I972), appeal docketed, No. 74-3212, 9th Cir., Nov. 20, 1974. See notes $217-34$ infra and accompanying text for a critique of this position. 
recognize that press interests require special protection which traditional fourth amendment doctrine by itself may not be capable of supporting. ${ }^{88}$

Free press. The media receive their most extensive constitutional protection from the first amendment's prohibition of governmental action abridging freedom of the press. ${ }^{39}$ Media functions that have been constitutionally recognized include gathering, ${ }^{90}$ editing, ${ }^{91}$ and distributing ${ }^{92}$ information. ${ }^{93}$ Most important, any government investigation forcing access to press information impedes the newsgathering function by threatening confidential sources with exposure, thus discouraging them from passing information to the press. ${ }^{94}$ However, a search and seizure may also, during its progress, physically disrupt all three functions. ${ }^{95}$

\section{Governmental interests.}

Combatting crime via search and seizure. The primary societal interest underlying law enforcement is "security for the person and property of the individual" from "reprehensible conduct forbidden to all other persons." In the attempts by police to provide that security, a search is one of the most effective tools. It often provides a swift means of obtaining such persuasive evidence of criminal activity as narcotics, contraband, or weapons. By quarantining illicit items, the search may prevent future crime as well as

88. See notes 217-34 infra and accompanying text.

89. U.S. Const. amend. I.

90. See Branzburg v. Hayes, 408 U.S. $665,68 \mathrm{I}$ (1972).

9I. See New York Times Co. v. United States, 403 U.S. 713 (I971); Wichita Eagle \& Beacon Publishing Co. v. NLRB, 480 F.2d 52 (Ioth Cir. 1973).

92. See Grosjean v. American Press Co., 297 U.S. 233 (I936).

93. For a case discussing all three of the interests listed in the text in the context of a press subpoena, see Bursey v. United States, 466 F.2d I059, 1084-85, reh. en banc denied, 466 F.2d rogo (9th Cir. 1972). The interests are more carefully analyzed with respect to searches and subpoenas at notes I 88-99 infra and accompanying text.

94. Cf. Branzburg v. Hayes, 408 U.S. $665,694-95$ (I972). See also V. BLASI, supra note I4; Murasky, supra note 27. These authors offer a fuller discussion of the societal importance of the interest in the free flow of information that populate the related area of governmental subpoenas of journalists.

95. See notes 188-90 infra and accompanying text. In addition, the past pattern of searching the underground or dissident press, see note 3 supra, imposes a discriminatory penalty on them for their editorial stances. See TwENTIETH CENTURY Fund, supra note 3, criticizing a "double standard of [law enforcement] treatment, one for the underground and one for the established press . . . that is inconsistent with the First Amendment's guarantee ...." Id. at 36, which occurs because "underground publications are almost always out of favor with the local governments and in bad odor with other influential circles of the communities where they are published. They have greater proclivity for antagonizing officialdom than the daily press ...." Id. at 34. Discriminatory pressures on the underground media may also affect nonpress interests in free expression because the informants, as well as patrons, of the underground press often "are members of a minority political or cultural group that relies heavily on the media to propagate its views," so that discriminatory police incursions against such media can have the dangerous effect of limiting public discussion of unpopular vievvs. Branzburg v. Hayes, 408 U.S. 665, 694-95 (1972). See Whitney v. California, 274 U.S. 357, 375 ( 1927 ) (Brandeis, J., concurring), for the classic statement of the dangers involved even in the suppression of what the majority deems "noxious doctrine," and A. Meiklejohn, FreE SPEEch AND ITS RELATION TO SELF-GovERNMENT 22-27, 37-39, 88-89 (I948), for discussion of the proposition that the first amendment's chief concern is not the theorists' right to express, but the voters' right to hear all sides of any question related to self-governance.

96. Branzburg v. Hayes, 408 U.S. $665,690,692$ (1972). 
help to convict the guilty. ${ }^{97}$ Thus far, police executing warrants against news media have sought anonymous communiques claiming credit for crimes or photographs of alleged criminal acts. ${ }^{98}$ To the extent that the police are denied the use of this technique, the prosecution of a given crime may become considerably more difficult or expensive. Clearly, the utter denial of access to this evidence when held by the press could impose significant costs on society.

Informed governmental dispute-solving. Combatting crime is only one aspect of the government's larger responsibility for providing society with peaceful adjudicative means of resolving disputes-whether between the government and criminal defendants or between civil litigants. To fulfill this role, the government must provide adequate access to relevant information not only in criminal investigations but in criminal and civil courts as well. Accordingly, common law courts since the I7th century have recognized what Dean Wigmore called the "fundamental maxim that the public .. . has a right to every man's evidence." ${ }^{\text {"9 }}$ Modern adjudication continues to stress the testimonial duty of all citizens, even to the point of suggesting that due process for litigants constitutionally requires it. ${ }^{100}$

However, the importance of the interest in the informed resolution of disputes can be overstated. Unduly aggressive insistence upon obtaining the fullest scope of "every man's evidence" may have counterproductive effects that outweigh society's need for the evidence. ${ }^{101}$ Thus, in the same section in which Wigmore discusses the duty of every person to testify, he cautions courts to "make the duty as little onerous as possible" given the infringement upon the witness' privacy. ${ }^{102}$ Efforts to make the least drastic demands on the witness actually enhance the ability of courts and government investigators to gather information. ${ }^{103}$ Inadequate sensitivity to the rights of witnesses would soon rob the courts of the respect on which their authority rests. ${ }^{104}$

97. See Detection of CRTMe 97-98 (L. Tiffany, D. McIntyre, Jr., D. Rotenberg eds. r966); O. Wilson \& R. McLaren, Police Administration 382 (3d ed. I972).

98. See note 3 supra.

99. $8 \mathrm{~J}$. WIGMORE, supra note 28 , at $\$ 2192$, paraphrasing Sir Francis Bacon in the Countess of Shrewbury's Trial, 2 Howell's St. Trials 769,778 (x6I2). Cf. C. McCormick, stupra note 28 , at $\$ 77$.

Ioo. See, e.g., United States v. Nixon, 418 U.S. 683, 709 (1974); United States v. Dionisio, 4I0 U.S. I, 9-Io (I973); Branzburg v. Hayes, 408 U.S. 665, 688 (1972); Blackmer v. United States, 284 U.S. 42r, 438 (1932); Blair v. United States, 250 U.S. 273, 279-8I (1919); cf. Stein v. New York, 346 U.S. 156, 184 (1953) ("The duty to disclose knowledge of crime rests upon all citizens. It is so vital that one known to be innocent may be detained, in the absence of bail, as a material witness.") See also Garland v. Torre, 259 F.2d 545, 549 (2d Cir.) (Stewart, J., sitting by designation), cert. denied., 358 U.S. 910 (1958).

IOI. See $8 \mathrm{~J}$. WigMORE, supra note $28, \S 22 \mathrm{ro}(\mathrm{r})$, at 152 .

I02. Id. $\$ 2192$, at 73 (emphasis in original); accord, C. McCormick, stupra note 28 , $\$ 4 \mathrm{I}$, at 82 .

103. The government's duty to temper its informational demands reflects a recognition of personal interests in privacy from governmental intrusion discussed at notes 80-88 stupra and accompanying text.

104. Even the privilege against self-incrimination has been supported on the ground that it sacrifices the courts' ability to wrest certain information from witnesses in the short run in order to 


\section{B. Branzburg and Its Aftermath: A Qualified Press Privilege with Respect to Subpoenas}

The major Supreme Court case to deal with most of these interests is Branzburg v. Hayes. ${ }^{105}$ Justice White's majority opinion in Branzburg purported to afford press newsgathering some first amendment protection from the inhibition of the flow of information from confidential sources to the media admittedly caused by subpoenas. ${ }^{106}$ But his opinion held that the investigatory needs of the grand jury ordinarily establish a compelling state interest sufficient to overcome the press interests. ${ }^{107}$ The emphasis of the opinion was upon one of the two press interests-unbridled press newsgathering-although Justice White did allude to the public's and the press' interest in freedom from harassment and uncontrolled intrusions by grand jury investigations. ${ }^{108}$

Justice Powell's "enigmatic"109 addendum to the 5-Justice opinion in which he concurred took an approach more sympathetic to the press. $\mathrm{He}$ explicitly balanced the press' interests in newsgathering and freedom from undue governmental interference in its private affairs by grand juries against society's need to fight crime and to have adjudicative bodies capable of compelling the production of necessary evidence. Although he found the press interests subordinate, he articulated a test for permissible subpoenas of the press considerably more solicitous of the interests of subpoenaed reporters than the majority opinion. Justice Powell would require a reporter to appear and to undergo questioning, but he suggested that the reporter could refuse to answer. Should the grand jury pursue the question

encourage them voluntarily to produce more evidence in the long run out of "respect for . . . the dignity of the judicial system." C. McCorsick, supra note 28 , $\$$ II 8 , at 252-53.

105. 408 U.S. 665 (1972). Branzburg actually involved three cases. Besides Branzburg v. Pound, $46 \mathrm{r}$ S.W.2d 345 (Ky., I970), the cases decided were In re Pappas, 358 Mass. 604, 266 N.E.2d 297 (197I), and Caldwell v. United States, 434 F.2d 108I (9th Cir. 1970). All three involved reporters called to testify before grand juries investigating allegedly criminal activity which the reporters had viewed in their role as newsgatherers. Paul Branzburg witnessed and described in a Kentucky newspaper the illegal use and synthesization of marijuana into hashish, 408 U.S. at $667-$ 7I; Paul Pappas, a television reporter, viewed activities at Black Panther headquarters in New Bedford, Massachusetts, during civil disorders there, id. at 672-75; Earl Caldwell was present at several speeches and interviews at which members of the Black Panther Party advocated violent revolution and the assassination of President Nixon, id. at 675-79. In Branzburg and Pappas, the Supreme Court upheld orders of the Kentucky and Massachusetts Supreme Courts, respectively, compelling the reporters' testimony. In Caldwell the Supreme Court reversed the Ninth Circuit, which, applying a balancing test similar to the one advocated by Justice Stewart, infra note Iro, had refused to order Caldwell to testify. The Branzburg trilogy is discussed in Murasky, supra note 27; The Supreme Coutrt I97I Term, 86 HaRv. L. REv. I03, I37-48 (1972).

106. See 408 U.S. at 681, 690-91. See id. 709-1o (Powell, J., concurring) and Apicella v. McNeil Laboratories, Inc., 66 F.R.D. 78,83 (E.D.N.Y. I975), stressing this aspect of Justice White's opinion.

107. 408 U.S. at $685-91,700$.

108. Id. at $688,707-08$.

109. The word is Justice Stewart's in his dissenting opinion. Id. at 725. Note also Justice Stewart's quip that Branzburg was decided by a vote of "four and a half to four and a half." "Or of the Press," Address by Justice Stewart, Yale Law School Sesquicentennial Convocation, Nov. 2, I974, excerpted in 26 HAst. L.J. 631, 635 (1975). 
by seeking a court order, the hearing judge would be required to strike a "case-by-case" balance between freedom of the press and the governmental interest in the information sought. ${ }^{210}$ Because Justice Powell's vote determined the outcome in Branzburg, his defense of a qualified degree of constitutional protection makes the Court's majority opinion less conclusive. ${ }^{111}$

Furthermore "the limited nature of the Court's holding"112 is manifest in the peculiar factual settings of the three cases decided under Branzburg. All of the plaintiff newsmen had actually witnessed the allegedly criminal activity under investigation by grand juries, rather than merely been informed of it, as is more often the case. Justice White pointedly stated in Branzburg that first amendment or any other considerations militating against testifying in those circumstances are insubstantial. ${ }^{113}$ The Court's

IIo. 408 U.S. at 709-ro (Powell, J., concurring). Elements in the balance would include the relationship of the information sought to the subject of the investigation and the legitimacy of the law enforcement need. Justice Stewart, with whom Justices Brennan and Marshall concurred, would have allowed newspersons to contest the validity of a subpoena prior to appearing before the grand jury. Before a press subpoena would be enforced by the courts, he would have required the government to show (a) that probable cause existed to believe that the newsperson had information clearly relevant to a specific crime, (b) that the information was unavailable through alternative means less inhibitive of press newsgathering abilities, and (c) that the grand jury had a compelling need for the information. 408 U.S. at 743 (Stewart, J., dissenting). Goodalc, Branzburg v. Hayes and the Developing Qualified Privilege for Newsmen, 26 HAst. L.J. 709, 7I7 (1975), argues that Powell's test does no more than change the burden of proof in Justice Stewart's dissent from the government to the reporter as to the strength of the government's need for the information sought. But Goodale's characterization erroneously equates Justice Powell's requirement of a "legitimate" law enforcement need with Justice Stewart's of a "compelling and overriding" one. Furthermore, he ignores the fact that Justice Powell would require the newsperson's appearance for testimony with challenges to specific questions only, while Justice Stewart's judicial balancing would preclude any forced appearance. However, with regard to physical evidence, Justices Powell and Stewart do advocate similar tests since process that commands the production of such evidence (subpoena duces tecum) is specific enough at the time it is issued to allow preproduction challenge even under Justice Powcll's test. This specificity contrasts with process which commands oral testimony (subpoena ad testificatum), since the details of that testimony are unclear until the witness undergoes questioning. All three cases in Branzburg, of course, involved the latter type of subpoena. However, the former is the proper analogue of a search warrant seeking physical evidence. Thus, five Justices favored a procedure requiring a chance for the press to challenge government demands for physical evidence before it is seized, since Justice Douglas would have protected reporters from all government subpoenas for evidence of crimes not allegedly committed by them. 408 U.S. at 721 (Douglas, J., dissenting). See Goodale, supra at 713-19 for a minute analysis of the different positions taken in the four Branzburg opinions.

III. See Goodale, supra note IIo, at 7I5. Goodale, General Counsel and Executive Vice President of the New York Times, treats the White opinion as a mere "plurality." A similar conclusion concerning the limited authority of Justice White's opinion is reached in Gunther, In Search of Judicial Quality on a Changing Court: The Case of Justice Powell, 24 STaN. L. REv. IO0r, I024-26 (I972).

Ir2. 408 U.S. at 709 (Powell, J., concurring).

II3. 408 U.S. at 692 . Justice White's ratio decidendi might be held to the following sentence: "Insofar as any reporter in these cases undertook not to reveal or testify about the crime he witnessed, his claim of privilege under the first amendment presents no substantial question." See People v. Marahan, 81 Misc. 367, 368 N.Y.S.2d 685, 69I (Sup. Ct. 1975) (distinguishing Branzburg on the strength of this language); cf. Lightman v. State, I5 Md. App. 7I3, 725, 294 A.2d I49, I54-55, aff'd, $266 \mathrm{Md}$. 550, 295 A.2d 212 (1972), cert. denied, 4II U.S. 95I (1973). Lightman discusses cases (including the Kentucky Supreme Court decision in Branzburg) that deny the protection of state shield laws covering "sources" to an "informer" who is simultaneously acting in the role of a perpetrator of crime. Branzburg and Lightman fit within the normal pattern of restricting privileged "communications" to things told to, but not to things seen by, the protected professional. Cf. C. MCCorMICK, supra note 28 , at $\S$ Ioo. 
reluctance to give up what is probably the best evidence relating to the relevant activity and its realization that this piece of evidence available to the newsperson would have existed whether or not the press was involved make this a particularly hard case for allowing a citizen-even a newsperson-to refuse to testify. ${ }^{114}$

Branzburg's holding is also narrow because all three reporter-plaintiffs refused even to appear before the grand jury in answer to five of the six subpoenas. ${ }^{115}$ Most of the cases before and since involve instead the refusal of a journalist in the midst of testifying to answer only certain questions bearing on matters allegedly privileged. ${ }^{216}$ The refusal to appear presents a more sweeping claim of exemption from every person's duty to offer evidence than does a refusal to answer selected questions. ${ }^{217}$ Furthermore, some of the differences between Justice Powell and the dissenters focus on problems relevant only to a subpoena ad testificatum, that is, one seeking oral testimony; there may be more agreement among them in cases involving subpoenas duces tecum, that is, ones seeking physical evidence. ${ }^{118}$

Branzburg may also be a limited precedent because of the narrow press interest involved in that case. The case concerns the "uncertain" effect of governmental intrusion upon only one of the several press functions discussed above: newsgathering. ${ }^{119}$ In cases where the governmental intrusion inhibits the press in its editing and disseminating functions as well, the courts may weigh first amendment interests more heavily. ${ }^{120}$ Moreover, Branzburg did not present as intense a threat to the fourth amendment interests in privacy as police searches of media offices. Thus, the "gloom"121

II4. This analysis was suggested by a discussion with Professor Jack Friedenthal of Stanford Law School, Dec. I, 1975. Professor Friedenthal distinguished testimony privileges (e.g., a spouse's privilege not to testify against a spouse) from confidential communications privileges (e.g., the lawyer-client privilege). He deemed the granting of the former privileges more likely to prevent information from reaching the courts because they deny the courts the witness' first-hand knowledge, which will exist whether or not the witness has a testimonial privilege. On the other hand, he noted that confidential communications privileges are less likely to impede the flow of information to the courts, since denial of these privileges would simply encourage the parties not to "make the evidence" by not participating in frank confidential communications.

II5. 408 U.S. at 670-79; see id. at 667: "The issue in these cases is whether requiring newsmen to appear and testify before state or federal grand juries abridges the freedom of speech and press guaranteed by the First Amendment. We hold that it does not." See Bursey v. United States, 466 F.2d I059, rehearing en banc denied, 466 F.2d Iogo (gth Cir. 1972) (refusing rehearing in light of Branzburg in part because of this distinction); Goodale, supra note IIo, at 713.

I16. See, e.g., Bursey v. United States, 466 F.2d I059 (9th Cir. I972).

II7. Reporters often refuse to appear because they feel that their inability to prove to their sources that they did not divulge confidential information in the secret grand jury proceedings will inhibit source from continued provision of information to the press. Caldwell v. United States, 434 F.2d ro8r (gth Cir. 1970), overruled by Branzburg, justificd a subpoenaed reporter's nonappearance on this basis.

II8. See note Iro supra.

II9. 408 U.S. at 682 ; see notes $90-99$ and accompanying text.

120. See Bursey v. United States, 466 F.2d I059, rehearing denied en banc, 466 F.2d rogo (9th Cir. I972).

12I. Goodale, supra note 27, at 133 . 
with which the press initially greeted Branzburg has gradually lifted as lower courts have emphasized its factual limitations and the Powell qualifications. ${ }^{122}$

\section{Beyond Branzburg: Comparative Impact of Subpoena and Search on Press and Governmental Interests}

The grand jury's role and its "essential" reliance on the subpoena provided crucial impetus for Justice White's decision in Branzburg, ${ }^{123}$ and for subsequent cases. ${ }^{124}$ Replacing the grand jury/subpoena analysis in Branzburg with one involving police investigations and search warrants leaves the press in a wholly different legal posture with respect to its rights to resist government evidence-gathering efforts. Not only do these investigatory de-

I22. See United States v. Liddy, 478 F.2d 586 (D.C. Cir.) (Leventhal, J., concurring), aff g 354 F. Supp. 208 (D.D.C. 1972) (Branzburg "controlled" by Justice Powell's opinion); Murasky, supra note 27, at 878, 915. For analysis of post-Branzburg cases, see Goodale, supra note II0; Murasky, sttpra note 27; 5 I N.C.L. Rev. I550 (I973). In the context of criminal investigations, the courts have provided a less uniform and more qualified newsperson's privilege. Nonetheless, all but one have applied a balancing test requiring some governmental showing of need to overcome the damage to first amendment interests before grand juries or trial courts can compel journalists to reveal sources or produce information. Compare Bursey v. United States, 466 F.2d ro59, rehearing denied en banc, 466 F.2d rogo (9th Cir. 1972), with United States v. Liddy, 354 F. Supp. 208 (D.D.C.), aff'd, 478 F.2d 586 (D.C. Cir. I972). Only a New Jersey Superior Court found in Branzburg a per se denial to newspersons of any immunization from governmental testimonial compulsion. In re Bridge, I20 N.J. Super. 460, 295 A.2d 3 (I972), cert. denied, 4IO U.S. 99I (I973). Subsequent state court decisions, even in criminal cases, have found a fairly protective journalist's privilege even while purportedly following Branzburg's logic. See cases cited infra. The factors weighing in the courts' balancing include those discussed supra notes 80-104 and accompanying text. The courts, taking Justice Powell's case-by-case approach, stress the particular weight of each interest under the circumstances of the case and often insist upon alternative governmental techniques that protect society's interests and yet avoid infringing first amendment interests. See, e.g., Baker v. F \& F Investment, 470 F.2d 778, 781 (2d Cir. 1972), cert. denied. 4II U.S. 966 (1973) (Branzburg does not "require disclosure of confidential sources in each and every case both civil and criminal"; a balancing test is required); Bursey v. United States, supra (three-part test: (a) immediate, substantial, subordinating government interest, (b) substantial connection between the information sought and that interest, (c) necessity of obtaining the information from the press). A panel of the Ninth Circuit decided Bursey prior to Branzburg, but the full court refused to hear it again based on that case, reciting several distinguishing, if originally not emphasized, factors discussed in notes II2-2I supra and accompanying text. The Bursey test, however, has transcended those distinctions and has been applied in several newsgathering cases since. See, e.g., United States v. Liddy, 478 F.2d 586 (D.C. Cir. r972) (Leventhal, J., concurring); In re Lewis, 384 F. Supp. I33, I40 (C.D. Cal. I974); In re Bensky, Misc. 75-I8-OJC (N.D. Cal., filed April 15, 1975). But see In re Lewis, 50I F.2d 4I8 (9th Cir. I974) (applying a less stringent test in a case not involving Butrey's distinguishing features); United States v. Liddy, 354 F. Supp. 208 (D.D.C.), affd, 478 F.2d 586 (D.C. Cir. 1972). While the picture is not much clearer than that painted by Justice White and retouched by Justice Powell in Branzburg, courts since, even in criminal cases, have highlighted a vague and qualified testimonial privilege and have made the situation brighter from the press' standpoint than some commentators persist in claiming. See Comment, supra note 19 , at $428-29$.

123. 408 U.S. at $685-96$, especially at 688 . Justice White's opinion should be viewed as a monument to the importance of unfettered grand jury investigation of crime, not as a gravestone over the rights of the press.

124. See, e.g., Bursey v. United States, 466 F.2d I059 (9th Cir. 1972). But see United States v. Liddy, 478 F.2d 586 (D.C. Cir.), aff' 354 F. Supp. 208 (D.D.C. I972), extending Branzburg to a trial court's subpoena of the press, though with little consideration of Branzburg's preoccupation with the grand jury. The following analysis deals mainly with the grand jury subpoena on the one hand and the police search warrant on the other. However, much of what is said concerning the procedural and judicial-supervisory protectiveness of the grand jury applies with equal or more force to trial courts that issue press subpoenas. 
vices transgress the same constitutional freedoms to different degrees; they also impact different constitutional interests. A police search, for example, invades fourth amendment individual privacy much more seriously than a subpoena, yet it also may serve more pressing societal needs for information. This section of the Note compares the effects of grand jury subpoenas and police search warrant procedures on the governmental and press interests discussed above to set the stage for a new balancing of them in the search situation.

\section{Grand jury subpoenas.}

Potential protection of press interests. Traditionally, the grand jury has served the role of a mediator between citizens and government prosecutors, ${ }^{25}$ and the press has historically benefitted from that mediation. A colonial New York grand jury, for example, opposed the prosecution of John Peter Zenger for seditious libel of the English government, ${ }^{126}$ and grand juries throughout the colonies refused to indict colonial journalists for their seditious libels against the Stamp Act. ${ }^{127}$ This historical affinity of grand juries for privacy and particularly for press interests persists today, albeit in new forms.

The conclusion of the United States Supreme Court that "the Constitution could not tolerate the transformation of the grand jury into an instrument of oppression"128 has enabled considerable court supervision of the grand jury. Although courts only rarely have been called upon to exercise this supervision and often have exhibited deference to grand jury proceedings, ${ }^{120}$ courts do have the power to assure that the grand jury does not exceed its powers in overzealous pursuit of its investigatory mandate. ${ }^{130}$

r25. See Branzburg v. Hajes, 408 U.S. 665, 686-87 (I972); Wood v. Georgia, 370 U.S. 375, 390 (1962); Hannah v. Larche, 363 U.S. $420,489-90$ (1960) (Frankfurter, J., concurring); $c f$. Comment, Grand Jury Proceedings: The Prosecutor, the Trial Judge, and Undue Influence, $39 \mathrm{U}$. CHI. L. REv. 76I, 764-65 (1972).

126. J. Alexander, A Brief Narrative of the Case and Trial of John Peter ZengerPrinter of the New York WeERIY Journal I7-I8, 45-48 (2d ed. I972).

127. See F. Motr, AMERICan Journalisas: A History of Newspapers in the UNIted STATEs Thmovgh 270 Years: 1690 to 1960 , at 103-08 (3d od. 1962).

128. United States v. Dionisio, 4I0 U.S. I, I2 (I973). See In re Grand Jury Proceedings, 486 F.2d 85, 9I-92 (3d Cir. I973), quoting United States v. Doe, 405 F.2d 436, 438 (2d Cir. 1968) (Friendly, J.): "[c]ven though evidence is not within a testimonial privilege, the due process clause protects against the use of excessive means to obtain it." See also id. at 91 (Schofield I), listing eight separate constitutional and nonconstitutional defenses to subpoenas duces tecum. The grand jury is sometimes erroneously mistrusted for the "almost total lack of limitations imposed upon its powers of inquiry." Comment, The Newsman's Privilege: Government Investigations, Criminal Prosecutions and Private Litigation, 58 CasIF. L. REv. 1198, 1239 (1970); see Branzburg v. Hayes, 408 U.S. 665, $744-45 \mathrm{D} .34$ (1972) (Stewart, J., dissenting). See also note I47 infra.

I29. In order to maintain the grand jury's mobility as a vehicle for fighting crime, the courts observe a presumption of regularity of grand jury proceedings. See, e.g., In re Grand Jury Subpoenas Duces Tecum, 39I F. Supp. 991, 994 (D.R.I. I975).

130. There are several aspects of judicial control over grand juries. The grand jury is an agent of the court, and grand jurors its officers, so that the court in most jurisdictions after (a) convening the grand jury may (b) discharge it for any or no reason, even before its work is completed, (c) in- 
Much of this supervisory power is exercised in response to witnesses' objections to grand jury assaults on their privacy. When ordered to testify pursuant to a subpoena ad testificatum, a witness may object via a motion to quash to prevent harassment or to declare the grand jury without jurisdiction via claims of immunity or via objections to specific questions as repetitious, irrelevant, or in search of privileged information. ${ }^{131}$ Despite the deference shown grand juries by the courts, ${ }^{132}$ such challenges occasionally succeed on the merits. ${ }^{133}$ Furthermore, the courts may find the subpoena valid and still partially defend witnesses' interests with protective orders limiting the testimony to specified areas or by ordering publication of the grand jury record to inform affected parties of the scope of the revelations made by the witness. ${ }^{134}$

struct the grand jury, (d) refuse to authorize payment of any of the grand jurors or jury's expenses, (e) discipline grand jurors or its officers (including prosecutors) or dismiss grand jury indictments because of breaches of secrecy or other duties, (f) prevent bad faith or harassing investigations, ( $g$ ) moderate any undue influence of the prosecutor, $(\mathrm{h})$ confine the grand jury's inquiry to its proper geographical and subject matter jurisdictions, (i) protect the rights and privileges (including testimonial) of witnesses before the grand jury, and (j) refuse to authorize or quash subpoenas issued by the grand jury. Of great importance, too, the grand jury must often go to court when it affects the rights of citizens from whom it demands evidence. The modern judicial trend, advanced by Branzburg, emphasizes the courts' power-indeed responsibility - to exercise a restraining force upon grand juries particularly when they threaten privacy and other rights of citizens called before them. Branzburg v. Hayes, 408 U.S. 665, 688, 707-08 (1972); id. at 710 (Powell, J., concurring). See United States v. Calandra, 4 I 4 U.S. 338, 346 (r974); United States v. Dionisio, 4 IO U.S. I, ro (r973); In re Grand Jury Proccedings (Schofield I), 486 F.2d 85, 92 (3d Cir. x973); Bursey v. United States, 466 F.2d x059, rehearing en banc denied, 466 F.2d 1090, 1091-92 (9th Cir. 1972); United States v. Smyth, 104 F. Supp. 283, 292-93 (N.D. Cal. 1952); Comment, Grand Jury Proceedings, The Prosecutor, The Trial Judge, and Undue Influence, 39 U. CHI. L. RE. 76r, 768-69 (1972); Comment, Constitutional Rights of Witnesses in Federal Grand Jury Proceedings: Bursey v. United States, I2I U. PA. L. Rev. 900 (1973). See also A. Amsterdam, stupra note 85, at $\$ \$ 163$, 172; L. ORField, Criminal Procedure Under THE Federal Rules § 6:108 (1966); Note, The Grand Jury as an Investigatory Body, 74 HARV. L. REV. 590 (I96I).

I3I. See In re Grand Jury Proceedings, 473 F.2d 840, 844 (8th Cir. 1973); Bursey v. United States, 466 F.2d To59, 1079-8I (9th Cir. I972); A. AMSTERDAM, stupra note 85, at $\$$ 163; 8 J. WigMORE, supra note 25 at $\$ 2210(\mathrm{I})$; Comment, The Rights of a Witness Before a Grand Jury, 1967 DukE L.J. 97, IOI-02. But see Blair v. United States, 250 U.S. 273, 282 (1919) (grand jury witness in federal court cannot object to irrelevant questions). A. AMSTERDAM, supra note 85 , at $\$ 16 \mathrm{I}(\mathrm{B})$, lists several other grounds upon which a grand jury witness may refuse to answer particular questions. Some states' grand juries are also required by statute to conduct their proceedings according to all the rules of evidence. All state and federal grand juries must at least honor testimonial privileges. See Fed. R. Evid. I IOY (d) (2); A. AMSTERDAM, supra note 85, at $\S 155$.

132. See note I29 supra.

133. See, e.g., Bursey v. United States, 466 F.2d I059 (9th Cir. 1972); United States v. Smyth, I04 F. Supp. 283, 292-93 (N.D. Cal. I952).

I34. Thus, for example, a subpoenaed attorney, reflecting his client's fears that appearance or production of documents before a grand jury might jeopardize the confidentiality of privileged information, may refuse to honor the subpoena. Should the court decide that the testimony or documents may be relevant, necessary and at least in part unprivileged, the witness may still seek a protective order limiting the questions or document requests to those which are relevant, necessary and nonprivileged. Cf. Branzburg v. Hayes, 408 U.S. 665, $7 x 0$ (I972) (Powell, J., concurring). In limited circumstances, the court may also order publication of parts of the grand jury record so that the witness may assure the client (or confidential news source) as to what was or was not revealed. See Transcript Rulings Before Judge Avakian, at 34, In re Death of Marcus Foster (Super. Ct., Dep't I, March 28, I974), ordering the grand jury to make public the questions it asked a reporter in order to apprise his sources of the harmlessness of his testimony from their point of view. See also In re Russo, 53 F.R.D. 564, 570-72 (C.D. Cal. I97I); C. McCorMIcK, supra note 28, at \$ II3. In some jurisdictions, counsel may even appeal to the grand jury's discretion by letter. See A. AMsterdoas, supra note 85 , at $\$ 164$. 
If the court denies the witness any relief from testifying, the grand jury may seek to enforce the subpoena by court order and court-imposed contempt sanctions. ${ }^{135}$ Even then, however, there remains a modicum of protection for the recalcitrant witness. Before any contempt santions can be imposed, the witness has a right to an unequivocal court order to respond to the subpoena $;^{136}$ if criminal contempt is involved, the witness can demand an explanation by the court of its basis for the charge as well as an attorney and a reasonable time for the preparation of a defense. ${ }^{137}$ Even after being cited for contempt, the witness may appeal that judgment before suffering any punishment. ${ }^{138}$ Thus, it is only after a full examination of the issues involved that an unwilling witness must suffer any penalty for resisting a subpoena.

Nonetheless, if reporters, like other witnesses, ultimately can be forced to testify before secret grand juries, confidential sources fearing identification in those proceedings will be reluctant to talk to the press. ${ }^{139}$ The Branzburg majority, however, held that the value to society of the subpoenaed testimony of reporters who have witnessed crimes overcomes the "consequential but uncertain" negative impact of the subpoena on protected newsgathering. ${ }^{140}$ Justice White downplayed subpoenas' inhibition of newsgathering because at most the source is forced to rely on the good faith of the reporter, with whom the informant often has a "symbiotic" or mutually trusting relationship. ${ }^{141}$ Their understanding may require that the newsperson go to jail, ${ }^{142}$ or it may simply require that the reporter reveal as little of the confidential material as the law allows in testimony that may be limited by court order to nonsensitive subjects or that may later be reproduced for the source as proof of the journalist's good faith. ${ }^{143}$ Thus, judicial supervision and procedural safeguards prevent subpoenas, in Justice White's words, from "requir [ing] the press ... indiscriminately to disclose" its sources. ${ }^{144}$

Of more practical significance regarding the protection of press interests is the opportunity for reevaluation of positions by all the participants in the subpoena process-the witness, witness' counsel, the grand jurors, the

135. Sce Brown v. United States, 359 U.S. 4I, 49 (I959).

136. See id.

137. See id.

138. See id.; cf. Farr v. Pitchess, 409 U.S. I243 (1973); Shillitani v. United States, 384 U.S. 364,37 I (1966); Nilva v. United States, 227 F.2d 74 (8th Cir. 1955); C. McCormick, supra note 28,592 , at 193 .

139. See generally V. BLASI, supra note I4.

I40. 408 U.S. at 690 .

I.4I. 408 U.S. at 694 .

r42. One study shows that in almost all cases in which the grand jury insisted upon a reporter's testimony, the newsperson accepted a contempt citation rather than testify. See Murasky, stupra note 27 , at 858 n.94.

143. See note 134 supra and accompanying text.

I44. 408 U.S. at 682 . 
government attorney, and the judge. At each stage of the process these people may propose ways to make the evidence available through means least damaging to the witness' interests. Thus, the adversarial nature of the proceeding causes constant reassessment of priorities by each participant to assure that only crucial interests of each are accommodated. For instance, every time a witness objects to the subpoena or refuses to answer a question, the members of the grand jury must agree, with the advice of a prosecutor and the consent of a judge, upon a procedure for pressing further its demands for evidence. With new input from these several perspectives, ${ }^{145}$ the grand jury must weigh the importance of the evidence sought against the administrative costs of pursuing it, considering the adamancy of the witness' refusal. ${ }^{146}$ After such reevaluation, the grand jury may decide voluntarily to withdraw the subpoena and, in so doing, protect the witness' interests. ${ }^{147}$

145. To the extent that exclusion of prospective grand jurors on racial, economic, ethnic, religious, or sexual grounds violates the due process and equal protection clauses, the grand jury's range of different perspectives is constitutionally mandated. See Alexander v. Louisiana, 405 U.S. 625 (1972); A. AMSTERDAM, supra note 85 , at $\$ 158$.

146. Branzburg v. Hayes, 408 U.S. 665, 694 (1972): "The reporter may never be called and if he objects to testifying, the prosecution may not insist." Cf. Comment, Grand Jury Proceedings: The Prosecutor, the Trial ludge, and Undue Influence, 39 U. CHI. L. REv. 76r, 765 (I972). Nor is it unimportant that the witness may delay (or accelerate) the production of evidence solely for personal convenience, should it also suit the convenience of the grand jury. See United States v. Doe, 457 F.2d 895 (2d Cir. 1972).

147. An example of the use of these techniques by a prospective grand jury witness illustrates their protectiveness. Three times a federal grand jury subpoenaed Harvard University professor Samuel Popkin concerning the illegal leaking of classified government documents to the press. He objected to all three subpoenas, claiming a privilege based upon academic freedom. Although Popkin lost each of the litigated challenges to the subpoenas, his five appearances before a trial court and one before an appellate court succeeded in encouraging the grand jury voluntarily to drop two of the subpoenas and some of the questions asked pursuant to the third. United States v. Doe, 460 F.2d 328 (Ist Cir. I972), cert. denied, 4II U.S. 909 (1973). Some modern criticism of the grand jury suggests that it functions as a "rubber stamp" for, rather than a potential protector of citizens from, zealous prosecutors who control the presentation of evidence and legal advice to the grand jury. A. AmsterdaM, supra note 85 , at $\$ 155$; see United States v. Kleen Laundry \& Cleaners, Inc., 38I F. Supp. 5 I9 (E.D.N.Y. I974). While this criticism generally objects to the lack of protection afforded the potential criminal defendant facing indictment, it also bears on the procedural and temperamental safeguards which this Note has argued the grand jury affords witnesses. For example, it is feared that the ability of the district attorney to examine witnesses before the grand jury in the absence of opposing counsel neutralizes the witness' statutory and procedural rights. See, e.g., A. AMSTERDAM, supra note 85 , at $§ 155$. However, even grand jury critics note that previously wellcounseled witnesses can thwart an overbearing prosecutor by steadfastly claiming their rights. This might initially encourage grand jurors to express their potentially independent and moderating views $-a$ not unheard-of-event. See $i d$., at $\$ 155,160-64$. See also the independent decision of the grand jury investigating the Watergate break-in and cover-up to name President Nixon as an unindieted coconspirator. E. DrEw, Washington Journal-The Events of I973-I974 287 (1974). In addition, a witness' continued refusal to respond will necessitate judicial intervention to compel testimony, if the prosecutor and grand jury press the inquiry. At that point, the process becomes adversarial. The courts have not ignored the possibility of abuses from prosecutorial autocracy. Indeed, the modern trend toward heightened judicial power over grand juries has included more exacting restraints on prosecutorial attempts to influence rather than inform the grand jury. See, e.g., State v. Joao, 53 Hawaii 226, 49I P.2d 1089 (197I) (indictment quashed because based upon the testimony of a witness who, the district attorney told the grand jury, wanted to make "a clean breast [of things]"); cf. Franklin v. State, 85 Nev. 382,513 P.2d 1252 , I255 (I973) ("In presenting a case to a grand jury a prosecutor... must scrupulously refrain from words or conduct that will invade the province of the grand jury or tend to influence the jurors in their judgment"). Given the criticism of the abuses of the grand jury, it is not surprising that the very opinions that have reaffirmed the centrality of the grand jury in American criminal prosecution have also reiterated the need and 
The majority in Branzburg alluded to the potential for press protection inherent in the good judgment and secret deliberations of grand juries. ${ }^{148}$ The court refused to apply to the grand jury the procedural and substantive safeguards developed by it to restrain legislative subpoenas that touch first amendment interests. ${ }^{149}$ In part this holding rests on the greater tendency of legislators than grand jurors needlessly to harass witnesses and upon the decorum associated with grand jury proceedings.

When a subpoena duces tecum is used, it most nearly achieves for the grand jury what search and seizure does for the police: the production of physical evidence. The procedural, practical and substantive protections afforded a person faced with a subpoena duces tecum exceed those of a recipient of a subpoena ad testificatum. ${ }^{150}$ Early in this century the Supreme Court in Hale v. Henkel ${ }^{151}$ determined that requests for documents by subpoena had to meet the fourth amendment requirement of reasonableness. ${ }^{152}$ Following Hale, the federal courts have allowed witnesses to object to the subpoena on fourth amendment reasonableness grounds, and the grand jury cannot obtain a court order enforcing the process until it fulfills its burden of proving reasonableness. ${ }^{153}$

potential for judicial control of the body. See cases cited in note 130 supra. Note also C. McCornricr, supra note $28, \S 137$, at 290 , regarding a modern trend to hedge grand jury proceedings with protective procedures.

I 48 . Branzburg v. Hayes, 408 U.S. 665,700 (1972).

149. See Gibson v. Florida Legislative Investigation Comm., 372 U.S. 539, 546 (I963) (legislators must prove a "substantial relation between the information sought and a subject of overriding and compelling state interest" before affecting first amendment interests).

150. United States v. Dionisio, 410 U.S. I, 10-12 (I973), notes the divergent protections afforded persons subject to the two types of subpoenas. Most of the protections afforded the recipient of a subpoena ad testificatum, discussed in notes $130-38$ supra and accompanying text, are available to the recipient of a subpoena duces tecum. See, e.g., Continental Oil Co. v. United States, 330 F.2d 347 ( 9 th Cir. 1964) (subpoena duces tecum naming privileged records is invalid); A. AMSTERDam, stipra note 85 , at $\$ 163$.

15I. 201 U.S. 43 ( 1906$)$.

152. Id. at $63-65,76$. The Court held that the grand jury must show both "some necessity" grounded on other evidence "to justify" production and a certain degree of specificity in the items named. In FTC v. American Tobacco Co., 264 U.S. 298, 306 (1924), Justice Holmes reiterated the fourth amendment requirement that "a ground must be laid" for a subpoena duces tecum. See United States v. Dionisio 4IO U.S. I, II-I2 (I973) (dictum). See also Application of Certain Chinese Benevolent and Dist. Ass'ns, I9 F.R.D. 97 (N.D. Cal. 1956). Because Hale and American Tobacco apply the fourth amendment, their analysis may bind the states under Mapp v. Ohio, 367 U.S. 643 (196r).

153. A subpoenaed federal witness overcomes the grand jury's presumption of regularity by showing that the subpoena is overly broad, nonspecific, or covers an unreasonably long period of time. The government must respond by showing necessity or reasonableness. See In re Grand Jury Proceedings (Schofield I), 486 F.2d 85 (3d Cir. I973), explained in In re Grand Jury Proceedings (Schofield II), 507 F.2d 963, 966 (3d Cir. 1975) (subpoena for handwriting exemplars, fingerprints, and mug shots must be accompanied by affidavits showing (a) the evidence's relevance and (b) that the primary purpose of the subpoena is as an aid to a grand jury investigation of matters (c) within the jury's jurisdiction; witness may use discovery proceedings to test the truth of the three affirmations in the grand jury's affidavit); In re Grand Jury Subpoena Duces Tecum, 39I F. Supp. 991 (D.R.I. I975); $c$. Universal Mifg. Co. v. United States, 508 F.2d 684, 686 n.2 (8th Cir. I975). Actually the Supreme Court cases could be read to require a showing of necessity and specificity to accompany all requests by federal grand juries for subpocnas duces tecum even if unchallenged, and one United States Circuit Court so requires in some circumstances. See In re Grand Jury Subpoena Duces Tecum, 391 F. Supp. 99I, $995-99$ (D.R.I. I975). 
Therefore, along with the procedural protection of the witness' interests discussed in relation to subpoenas ad testificatum-total or partial judicial protection based on the merits of the witness' refusal and the reevaluation of priorities by all participants in the procedure-the witness subject to a subpoena duces tecum has the additional advantage of placing the burden of justifying production on the government. Of supreme importance, of course, is the availability of this entire protective apparatus before any testimony with harmful effects on newsgathering takes place. Justice White in Branzburg stressed all of these press-protective characteristics of the subpoena process-judicial supervision, amenability to prior challenge, and secrecy of grand jury deliberations-in concluding that subpoenas' limited harmful effects on the press were outweighed by their societal value. ${ }^{154}$

Grand jury subpoenas' potential for serving governmental interests. The most recent Supreme Court cases considering the grand jury have emphasized its "important, constitutionally mandated role" in "effective law enforcement aimed at providing security for the person and property of the individual." ${ }^{\text {155 }}$ Grand jury investigations and indictments provide the most often-used avenue to the prosecution of serious crime in most American jurisdictions. ${ }^{150}$ And the Supreme Court has held that the subpoena is "essential"157 to the grand jury's fulfillment of its law enforcement task. Without the subpoena, the grand jury would have no authoritative means of acquiring testimony or commanding the production of evidence before it. While occasionally government prosecutors are accorded the subpoena power, most states reserve it to the grand jury. ${ }^{158}$ Consequently, in most jurisdictions, utilization of the subpoena requires the empanelment of a grand jury. Grand juries are generally empanelled throughout the year, ${ }^{159}$ although some states have fairly elaborate procedures for assigning a specific case to a grand jury enabling it to issue necessary subpoenas. ${ }^{160}$ Despite its importance to the grand jury (which is in turn crucial to American criminal

154. Branzburg v. Hayes, 408 U.S. $665,700,707$ (I972).

I55. Id. at 690 (I972); see id. at 688, 700; United States v. Calandra, 414 U.S. 338 (I974); Costello v. United States, 350 U.S. 359, 362 (I956); Blair v. United States, 250 U.S. 273 (rgr9); United States v. Smyth, ro4 F. Supp. 283, 289-90 (N.D. Cal. I952).

156. The fifth amendment mandates grand jury indictment for serious federal offenses. U.S. Const. amend. V. While not applied to the states through the fourteenth amendment, Hurtado v. California, IIo U.S. 516 (1884), most states have similar constitutional requirements. See Branzburg v. Hayes, 408 U.S. $665,687-88$ (1972); A. AMSTERDAM, supra note 85, at $\$ \$ 20$, I53. But see Judicial Counce. of California, I974 Report to the Governor and the Legislature 30, 42, noting that only $3.8 \%$ of all California felony prosecutions in 1972 were initiated by grand juries.

I57. Branzburg v. Hayes, 408 U.S. 665, 688 (I972); see A. AMSTERDAM, supra note 85, at $\$ 20$. I58. See note 5I supra and accompanying text.

I59. See A. AmsterdaM, supra note 85 , at $\$ \$ 20-21,153-55$ for a discussion of grand jury procedures.

I6o. For example, in California a grand jury will not handle a case until assigned to it by a criminal complaint committec. Even then, once the grand jury is empaneled and convened, the body is technically free not to accept the case. See generally Petersen, The California Grand Jury System: A Review and Suggestions for Reform, 5 PAc. L.J. I (I974). 
prosecution), the subpoena occasionally may not afford rapid governmental acquisition of evidence. ${ }^{161}$

The governmental interest in a potent subpoena power extends beyond its use in acquiring evidence of criminal activity. Many government institutions other than grand juries and prosecutors, including courts, administrative agencies and legislatures, depend on such process to acquire vital information. The strength of every citizen's duty to provide the public with available evidence $e^{102}$ is diluted when the subpoena power is qualified. To the extent that they rely on public responsibility, government agencies could seriously suffer from that dilution.

\section{Press searches.}

While serving many of the same and some additional governmental interests as grand jury subpoenas, searches and seizures-even when buttressed with a warrant-are harsh, inflexible, and less protective of press interests than the subpoena. Historically, search procedures have received their greatest criticism when applied to the press: the libertarian dissatisfaction with uncontrolled searches that culminated in the fourth amendment's limits on all searches arose only after the I8th century English government began using unrestrained searches against the press. ${ }^{163}$ Even today, the search remains problematic when applied in the press context ${ }^{164}$ where, because of first amendment considerations, the Supreme Court has traditionally required carefully drawn government procedures. ${ }^{165}$ In par-

16r. Once the grand jury is empaneled and convened, the subpoena process requires time in identifying, locating, and serving the subpoenaed witness, and may take additional time if the witness moves to quash.

I62. The testimonial duty of all citizens and its enactment via subpoena are discussed at notes 99-104 supra and accompanying text.

163. See Stanford v. Texas, 379 U.S. 476,482 ( 1965 ). For example, the use of searches to enforce seditious libel laws against the opposition presses of men like John Wilkes prompted the first judicial efforts to regulate oppressive criminal law enforcement procedures. See, e.g., Wilkes v. Wood, I9 Howell's St. Trials II53 (I763); N. LAsson, supra note I6, at 42; L. LEvY, sapra note I6, at I45-47. A similar dissatisfaction motivated colonial officials in New York to refuse to carry out the English Governor's order to seize and burn John Peter Zenger's journal. See J. Alexander, supra note r26, at $17-18,45-48$.

164. See, e.g., Roaden v. Kentucky, 413 U.S. 496, 504 (1973) ("a higher hurdle in the evaluation of reasonableness" of searches is due when first amendment interests are present).

I65. The Court requires that if first amendment interests must suffer in the name of a higher social value, the procedure used must be "tailored as precisely as possible to the exact needs of the case." Carrol v. President \& Comm'rs of Princess Anne, 393 U.S. I75, I84 (I968). Legal procedures, "devices and doctrines [that] in most applications [are] consistent with the Constitution" have received the Supreme Court's disapproval because "they have the collateral effect of inhibiting the freedom of expression." Smith v. California, 36I U.S. I47, 150-5I (I959). Indeed, the first amendment implicitly includes a body of procedural safeguards-i.e., a "due process" all its own. See Monaghan, First Amendment "Due Process," 83 Harv. L. Rev. 5 I8 (I970). The Supreme Court generally insists on first amendment due process in cases in which both the substance of the law being enforced and its procedures affect first amendment interests. See, e.g., Heller v. New York, 413 U.S. 483 (1973) (obscenity); Stanford v. Texas, 379 U.S. 476 (1965) (criminal syndicalism); New York Times Co. v. Sullivan, 376 U.S. 254 (1964) (libel). In the case of police investigations of criminal activity in which the press is not implicated, the substantive law in question concerns activity unrelated to first amendment interests. Arguably, the threat to press rights is greater where 
ticular, the search procedure lacks the procedural and practical protections inherent in the subpoena process upon which Justice White depended in Branzburg to denigrate the subpoena's adverse press effects. ${ }^{168}$ Indeed, since even illegally seized evidence may become the basis for grand jury inqui$\mathrm{ry}^{\mathrm{T}}{ }^{\mathrm{Br}}$ it is simple to apply Branzburg's first amendment analysis to condemn searches. Insofar as every search and seizure potentially entails later presentation to the grand jury of items thus discovered, execution of a search warrant has as significant a first amendment impact as such presentation by subpoena. The existence of any additional first amendment consequences from the search and seizure ipso facto would make that process more harmful to the press than Branzburg found the subpoena to be. Many such consequences do accompany the search process.

Search warrants harmful effects on press interests. At first glance, the search and seizure process resembles the grand jury subpoena procedure in several ways. First, there is judicial input because only a neutral, detached judicial officer may issue a warrant. ${ }^{188}$ However, upon closer scrutiny, the apparent protectiveness of this judicial input shrinks. The magistrates and police judges who issue search warrants are often people in whose decisionmaking the legal system reposes less confidence, given their limited responsibility and authority. Working closely with the police-often physically located in the same offices-these magistrates are likely to have a symbiotic rather than a supervisory relationship with the police. ${ }^{169}$ This judicial attitude is clearly less protective than that of courts supervising grand juries.

Second, similar to the requirement that a grand jury show a reasonable need for the evidence to justify production under a subpoena duces tecum, ${ }^{\mathbf{1 7 0}}$ the court is authorized to issue a search warrant only upon a showing of probable cause. ${ }^{171}$ Again, however, the protective veneer of this requirement fades when its actual application is examined. The requesting police

both the substance and procedure of the law impede first amendment activity. But the distinction evaporates under closer scrutiny. However admirable its object, any procedure with a "collateral effect" repugnant to first amendment values deserves disfavor. Smith v. California, 361 U.S. I47, I50-5I (I959); see Watkins v. United States, 354 U.S. I78 (I957). Although the Court has repeatedly sanctioned prosecution of obscenity, libel, inflammatory speech, and criminal action prompted by political beliefs, it has cautioned that the proximity of first amendment interests to those evils requires that the government, in its haste to eradicate them, take care not to trample free cxpression. No less should be required when the government seeks to pursue evidence of the evil of criminal conduct across the press' doorstep.

I66. See note 148 supra and accompanying text. Contra, Murasky, supra note 27, at 886-87;

86 HARv. L. REv, 1317, 1332 (1973).

I67. See United States v. Calandra, 4r.4 U.S. 338 (I974).

r68. See Johnson v. United States, 333 U.S. Io, I4 (r948).

I69. See, e.g., Thompson v. Stahl, 346 F. Supp. 40I (W.D.N.C. I972) (contempt of a magistrate not same as contempt of court in certain circumstances).

I70. See notes $150-53$ supra and accompanying text.

I7. Probable cause requires proof of sufficient facts to warrant a person of reasonable caution in the belief that the article sought evidences criminal activity and at present is located in the place named in the warrant. See Aguilar v. Texas, 378 U.S. 108 (1964); Brinegar v. United States, 338 U.S. I60, I75-76 (1949); Johnson v. United States, 333 U.S. 10, I3-I4 (1948). 
officer may base the factual allegations in the affidavit supporting probable cause upon the observations of informants-even those of uncertain reliability. ${ }^{172}$ In addition most states and some federal courts do not even allow the victim of a search to challenge a search after it has occurred by impeaching the averments in the affidavits accompanying the warrant request. ${ }^{173}$ Further, the finding of probable cause is made ex parte, without the assistance of argument from opposing counsel; the opinion is based instead upon papers "normally drafted by non-lawyers in the haste of criminal investigations." 174

Similarly, the burden on police officers to show probable cause seems in theory more protective of the person searched than the burden on grand juries to show mere reasonableness in justifying a subpoena duces tecum. A comparison of the practical applications of the two burdens, however, reveals less protection than perceived in theory. While a grand jury must show necessity, ${ }^{175}$ a mere showing that the item sought is relevant, ${ }^{176}$ even if comparatively unimportant, to a criminal investigation will justify intrusion under a search warrant despite an overriding privacy interest that the owner might have. ${ }^{177}$ Further, and of particular importance to this Note, the probable cause showing required for a search warrant lacks the adversarial input that in the subpoena context assures consideration of the public, statutory, and even constitutional policies that may otherwise allow a reporter to withhold information sought by the government. Indeed, the entire search warrant procedure, unlike the grand jury subpoena system, thwarts any introduction of such policies into the decisionmaking process: the ex parte decision to issue the warrant is followed by the speedy execution of the warrant by the police officer. ${ }^{178}$

Thus, the possibility of any effective intervention and objection by the affected citizen prior to police intrusion is negated; only insufficient post facto remedies are available. ${ }^{179}$ In all American jurisdictions except California the most important societal device for curbing wrongful searches-

I72. See Jones v. United States, 362 U.S. 257 (I960); A. AMSTRRDAM, supra note 85, at $\$ 241$.

I73. United States v. Ventresca, 380 U.S. I02, 108 (I965). The Court therefore authorizes magistrates to issue warrants without recourse to "[t]echnical requirements of elaborate specificity." Id.

174. Even those courts allowing such a challenge seem to require purposive misrepresentations or comparable bad faith on the affiant's part. See North Carolina v. Wrenn, 4I7 U.S. 973 (I974) (White, J., dissenting from denial of certiorari); A. AMSTTERDAM, supra note 85, at $\$ 24 I$.

I75. See notes $150-53$ and accompanying text.

I76. See note I7I supra.

777. Compare this to the subpoena situation where the persistent objections of a subpoenaed person invoke the grand jury's reevaluation of the items' true importance. See notes r45-47 supra and accompanying text.

178. See, e.g., United States v. McClard, 333 F. Supp. 158, 164-65 (E.D. Ark. 197r).

179. If the citizen chooses to resist official execution of a warrant, "[w] thout the slightest hesitation his doors would be broken down, he would be placed under arrest, and the desired material would be scized." VonderAhe v. Howland, 508 F.2d 364, 373 (9th Cir. I974) (Ely, J., concurring and dissenting); see note 72 supra and accompanying text. 
the exclusionary rule-does not apply if the victim of the search is not also the defendant ${ }^{180}$ Even if subsequently indicted, the victim in most jurisdictions may not complain if the grand jury that issued the indictment asked questions based on illegally seized evidence. ${ }^{181}$ And for the nonsuspect victim, lacking even the exclusionary rule's deterrent, the remedies are far from ample. ${ }^{182}$ Particularly if the police act pursuant to a search warrant, even one later found to be based upon erroneous or insufficient facts, the victim may do little more than seek return of the items seized. ${ }^{183}$

The sparseness of information upon which the probable cause decision is made, the absence of adversarial input before that decision sanctions incursions against press interests, the insensitivity toward those interests of the substantive test for making the decision, and the weakness of after-thefact remedies if that decision is incorrectly made withhold from press interests precisely the safeguards that the Supreme Court normally requires in first amendment situations. ${ }^{184}$ Those characteristics of the search warrant are

I80. Compare Alderman v. United States, 394 U.S. I65 (I969), with People v. Martin, 45 Cal.2d 755, 290 P.2d 855 (1955). See also Amsterdam, supra note 16, at 360-6r.

I8r. United States v. Calandra, 4 I 4 U.S. 338 (1974).

I82. People v. Warburton, 7 Cal. App. 3d 8I5, 824, 86 Cal. Rptr. 894, 899 (2d Dist. I970), used precisely this logic to refuse to allow a criminal defendant to exclude material unconstitutionally subpoenaed from another party, despite California's rule allowing the defendant to exclude material unlawfully seized from a third party: "When police unjustifiably enter an office and seize papers, privacy is irrevocably destroyed. But the issuance and service of a subpoena do not, by themselves, invade the private papers of anyone. If the person having custody of the papers believes the subpoena is defective ... he may make a motion to quash the subpoena . . or he may refuse to comply and present his excuse when enforcement is attempted against him ...."

I83. See A. Amsterdam, supra note 85, at $\$ 224$. "Good faith" and "pursuant to official duty" defenses completely immunize the magistrate from an action claiming violation of rights due to a search. The same defenses virtually do the same to police officers. See Pierson v. Ray, 386 U.S. $547,554,557$, I967); cf. Wood v. Strickland, 420 U.S. 308 , 3I7 (1975). See also Bivens v. Six Unknown Named Agents of the Fed. Bur. Narcotics, 456 F.2d I339 (2d Cir. I972). In addition, litigants suing federal officers must meet the $\$ 10,000$ amount in controversy requirement of 28 U.S.C. \$ I33I (a) (I970). See Amsterdam, supra note I6, at 360 nn.I37-38.

I84. First amendment due process, see note 165 and accompanying text, generally requires that a judge with the aid of opposing counsel must decide whatever interests affected by governmental procedure are indeed protected under the first amendment, and must do so before or as soon as possible after the infringement of those interests. If the interests are found protected, the infringement may not proceed, or must cease immediately. See Heller v. New York, 4I3 U.S. 483 (I973); Oestereich v. Selective Serv. Local Bd. No. II, 393 U.S. 233, 243-44 n.6 (I968) (Harlan, J., concurring); Freedman v. Maryland, 380 U.S. 5 I (Ig65). In contrast to the subpoena process, the probable standards for third party search warrants allow no prior (nor usually any) judicial or adversarial consideration of whether the items sought deserve first amendment protection. This immediate hearing rule, developed in obscenity cases, should be stricter with regard to press searches. The seizure for evidence of one allegedly obscene book or film of which copies are available for continued dissemination has only slight first amendment impact. See Heller v. New York, 413 U.S. 483, 492-93 (1973). However, the moment police officers enter a press facility in search of confidential information relating to criminal activity, severe first amendment impact has already occurred. From that point on, whatever fear of disclosure informants had earlier felt will be enhanced. The police's ability to intrude without any concomitant ability on the part of the source to receive renewed assurances by the newsgatherer may cut off further source cooperation. See notes rgo-99 infra and accompanying text. Justice Jackson fittingly noted the inconsistency of the normal search process and the traditional protections available to first amendment interests: "We must remember, too, that freedom from unreasonable search differs from some of the other rights of the Constitution in that there is no way in which the innocent citizen can invoke advance protection. For example, any effective interference with freedom of the press, or free speech, or religion, usually requires a course of suppressions against which the citizen can and often does go to the court and obtain an injunction." Brinegar v. United States, 338 U.S. r6o, I82 (1949) (Jackson, J., dissenting). 
also contrary to the protections available to the subpoenaed witness and relied on in striking the Branzburg balance against the press. ${ }^{185}$ In at least four ways the search procedure more severely impinges upon press interests than the subpoena procedure contested in Branzburg; this more severe impact almost certainly tips the delicate balance ${ }^{188}$ in favor of protection against searches.

First, even the most assiduously legal procurement and execution of a search warrant more severely invades the privacy of its intended recipient than does a subpoena. A police officer executing a search warrant is in no sense bound to the secrecy and quasi-judicial decorum of grand jury proceedings. An officer is, in fact, authorized to break, enter, and even ransack when necessary, subjecting the affected citizen to whatever invasion of privacy that may entail. ${ }^{187}$

Second, unlike the grand jury subpoenas at issue in Branzburg, the effects of searches fall not only on newsgathering but also upon the media's editing and disseminating functions. A search may severely disrupt the functioning of the entire press facility for several hours. When the item sought is a letter or photograph, ingress to files, desks, broadcast booths, or paste-up rooms may be unavoidable. Newspapers in particular tend to accumulate notes, back issues, and photographs. The presence of police officers rifling through these files cannot but disrupt normal functions-functions that at many press facilities continue around the clock. ${ }^{188}$ This disruption not only impedes timely publication or broadcast but effectively exacts a fine or tax in the amount of salaries of employees either made idle by or required to clean up after the police officers. ${ }^{189}$ It also establishes a potentially discriminatory penalty against any media concern likely to receive and feel obligated not to disclose certain information. ${ }^{190}$ Thus, not only does the search itself

185. See note 144 supra and accompanying text.

186. See note $2{ }_{4}$ infra and accompanying text.

187. See United States v. Doe, 405 F.2d 436, 438 (2d Cir. 1968).

188. See Memorandum of Points and Authorities in Support of Plaintiffs' Motion for Summary Judgment at Io, Stanford Daily v. Zurcher, 353 F. Supp. 124 (N.D. Cal. I972), appeal docketed, No. 74-3212, 9th Cir., Nov. 20, 1974, quoting affidavit of CBS News Director Gordon Míanning: "To allow this kind of free-wheeling search [like the one of the Stanford Daily offices] is to invite more searches, since a working newsroom contains an abundance of information, much of which would be argued by investigators to be useful ... Not only would these news gathering and reporting functions be inhibited in an exaggerated but a similar way to which the subpoena power inhibits, but also the very ability of a news organization to operate would be threatened. A search warrant presumes that material must be sifted before the needed material is located. I can imagine the working of a newsroom being brought to a complete halt while this voluminous and as yet unorganized information is "searched.'"

18. Note, for example, that the search of KPFK-FM in Los Angeles lasted over 8 hours. 6 PCN at 30, sutpra note I. See Stanford Daily v. Zurcher, 353 F. Supp. 124, I35 (N.D. Cal. 1972), appeal docketed, No. 74-3212, gth Cir., Nov. 20, 1974; 86 HARv. L. REv. 1317, I333 (1973); cf. Murasky, supra note 27 , at $862-64$.

rgo. Of course, only the journalists' refusal (or inability) immediately to produce the item named in the warrant triggers a disruptive search. Yet the tendency of members of the press in the past to refuse to disclose confidential information, even after cited for contempt, suggests that in most cases the police will be forced to search the premises. See Murasky, supra note 27 , at 
disrupt media functions, but the mere threat of a search may affect newsgathering and editorial policy. ${ }^{191}$

Third, the detrimental effect of searches upon newsgathering far outstrips the harm that Justice White found "consequential but uncertain" in Branzburg. ${ }^{192}$ Unlike the subpoena situation, the reporter's loyalty to his informant is meaningless in the face of a search; should the reporter block the search, the police will force him aside. While legally bound to confine their search to items specified, police officers have access to material in almost any file once the news office refuses simply to hand over the item named in the warrant. ${ }^{193}$ The officers' scrutiny may blanket any portion of the named location where the specified items might reasonably be located -a limitation that allows virtually free access to the entire premises if the item sought is small and easily capable of concealment. ${ }^{194}$ Moreover, in the course of that authorized scrutiny, the officers may inadvertently discover other unspecified, incriminating evidence. The officers may seize any evidence of criminal activity properly named in the warrant and any items inadvertently found in the authorized search. ${ }^{195}$ Anyone whose name or whose confidential information - whether at all related to the particular matter being investigated - might be in one of those files will justifiably fear exposure. ${ }^{106}$ Under similar circumstances, courts have been reluctant to leave the degree of first amendment infringement to the "whim" of "zealous offcers." ${ }^{\text {"197 }}$ Police discretion is particularly troublesome here since its impact is measured by the reactions of people especially unlikely to trust law enforcement personnel to restrain their searches. ${ }^{108}$ Justice White downgraded first

858 n.94 (study showing $96 \%$ refusal by journalists to obey court orders to reveal confidential information).

I9I. These effects, not found in Branzburrg, have provoked judicial prohibition of the offending procedure in other cases. Merely by imposing extra "cost in printing and composing time and materials," a Florida right-to-reply law, while itself supportive of other free expression rights, was deemed an unconstitutional burden upon the press. Miami Herald Pub. Co. v. Tornillo, 418 U.S. $24 \mathrm{I}, 256$ (1974). The threat to the press created by the potentially high costs of libel awards has also motivated court restrictions. Compare Branzburg v. Hayes, 408 U.S. 665, 68I (r972), with New York Times Co., 376 U.S. 254 (I964). Furthermore, courts have held that the greater the impact of governmental advertising regulations on publishers and editors, the less likely it is that they will withstand judicial scrutiny. See Bigelow v. Virginia, 42r U.S. 809 (1975).

192. 408 U.S. at 700,709 .

193. Thus when searching for a one-page document or a photograph, the police must read or examine every document or photograph in the office until they find the specified one.

194. See, e.g., Warden v. Hayden, 387 U.S. 294 ( 1967$)$.

195. Coolidge v. New Hampshire, 403 U.S. 443, 465-70 (I97r); see, e.g., Warden v. Hayden, 387 U.S. 294, 299-300 (1967) (proper to search for weapon in washing machine and to seize clothes found there though not originally sought).

196. See Note, Reporters and Their Sources: The Constitutional Right to a Confidential Relationship, 80 Y ALE L.J. 3 I7 (1970).

I97. Stanford v. Texas, 379 U.S. 476,485 (1965); Johnson v. United States, 333 U.S. Io, I3 (1948); see Marcus v. A Search Warrant, 367 U.S. 717 (196r). Note also Lovell v. Griffin, 303 U.S. 444 (1938), which found unconstitutional an ordinance limiting legal distribution of literature on city streets by a licensing scheme because it left the decision to issue a license totally in the City Manager's descretion. See Cox v. New Hampshire, 3I2 U.S. 569 (I94I). Similar unbounded executive discretion characterizes the execution of search warrants.

I98. See Memorandum of Points and Authorities in Support of Plaintiffs' Motion for Summary 
amendment impact of subpoenas in Branzburg because they do not "require the press . . . indiscriminately to disclose" its sources $;^{199}$ searches, on the other hand, open the press' files wide.

Fourth, lower courts have accepted Justice Powell's balancing test as authoritative. If they are correct in doing so, present search procedures are insufficiently protective of the freedoms at stake. The two-part probable cause test $^{200}$ for a search warrant ignores competing societal and press interests, the relative weights of which Justice Powell claims should decide the government's right to information in the hands of the press. ${ }^{201}$

The importance of search warrants in accomplishing governmental goals. Balanced against the search warrant's more detrimental impact on press interests are those occasional governmental interests that only the warrant can serve. On the one hand, warranted searches do not play a statistically important role in criminal investigations. Whenever possible police officers eschew warrants: they are utilized in less than to percent of all searches and then usually in the prosecution of crimes, especially vice, unlikely to result in press involvement. ${ }^{202}$ And police have at their disposal

Judgment at x4, Stanford Daily v. Zurcher, 353 F. Supp. 124 (N.D. Cal. 1972), appeal docketed, No. 74-3212, 9th Cir., Nov. 20, 1974, quoting CBS commentator Walter Cronkite: "Included in news material which is not broadcast ... is information obtained in confidence or under restrictive conditions from sources that would perbaps be of particular interest to the police, the FBI, or other governmental agencies. It has been my experience that exposure, for whatever reason, of such unpublished information would have the chilling effect of cutting off that source in the future. Further, once a practice has been established that threatens such exposure, the knowledge would have a chilling effect on all other sources which might prefer to remain anonymous .... While the potential of such a chilling effect is great when more common tools such as the subpoena power are used, the "fishing expedition' nature of a search warrant makes it a particularly dangerous threat."

I99. 408 U. S. at 682 .

200. See note I7I supra and accompanying text.

20I. See notes IO9-10 supra and accompanying text. The use of search warrants directed solely to the underground press, see note 3 supra, raises additional first amendment questions not present in Branzburg. In that case, Justice White voiced a concern-which has prompted him elsewhere to disagree with press protection afforded by his colleagues-that in many cases the press "has at its disposal powerful mechanisms" to protect itself from government intrusion without judicial help. 408 U.S. at 706; see Gertz v. Welch, 4 I8 U.S. $323,390-9$ I (I974) (White, J., dissenting); cf. G. TALESE, The Kingdom and THE Power (I97I). In Branzburg, where Justice White viewed the effects of that intrusion as uncertain, the powerful and established press was thought to need no protection. Admittedly, the New York Times survived the loss of reporter Caldwell's contact with the Black Panthers resuiting from the Court's refusal to privilege the reporter. Such would not likely be the case with a struggling underground newspaper. Insofar as searches, unlike subpoenas, have discriminatorily concentrated on the dissident press, and insofar as the former procedure may cause more severe physical disruption than the latter, the continued allowance of searches poses a greater threat to the free flow of ideas than do subpoenas. Surely the Court that was indignant at the effect of a $\$ 500,000$ libel judgment against the Times, see New York Times Co. v. Sullivan, 376 U.S. 254 (I964) would be no less so at what amounts to greater impositions on the "radical press" facilities most likely to suffer a search. Victims of press searches may represent dissident political viewpoints and serve, as well as provide, media access to similarly dissident groups; a search's ability to cripple these operations represents insufferable first amendment consequences. See id. at 294 (Black, J., concurring); cf. Stanford v. Texas, 379 U.S. 476 (I965).

202. See DeteCtion of CRIME, supra note 97 at 99-104. This work notes that the "search warrant is rarely used by police even since the Supreme Court expressed its preference for it." $1 d$. at I00. The most common uses of warrants is in the prosecution of vice (narcotics, alcohol, gambling, prostitution), and only then when (a) there is "an overriding desire by police to conduct a search which courts will hold to be lawful" (b) and usually then only "when the desire is to search several 
myriad alternative means of obtaining significant amounts of information -observation, surveillance, "tips," informers, access to public records, as well as interrogations of victims, third parties and suspects. ${ }^{203}$

On the other hand, in rare cases police do depend upon warranted searches. ${ }^{204}$ When swift action is necessary to acquire evidence, and its possessor will not cooperate, police may have to resort to a search. Alternatively they may apply to a grand jury or prosecutor for a subpoena but that process is often time-consuming. ${ }^{205}$ Thus, when the police, despite criminal laws prohibiting ${ }^{206}$ and court orders restraining ${ }^{207}$ such activity, fear imminent destruction of crucial evidence, a search may be imperative. ${ }^{208}$ Only in this case does the search become as "essential" to criminal investigation as the Supreme Court in Branzburg found the grand jury subpoena always to be. ${ }^{209}$

However, the search procedure never rises to the level of importance assigned to the subpoena in facilitating evidence-gathering by the courts. As discussed earlier, enforcing the duty of citizens to provide information is a major means by which legislative and administrative agencies and especially courts and grand juries acquire evidence. ${ }^{210}$ The subpoena power (a power usually withheld from law enforcement officials) statutorily endorses this information-gathering effort. ${ }^{211}$ Consequently government agencies in most jurisdictions count on grand jury subpoenas rather than searches or other police activity to bring evidence and witnesses before them. Moreover, the corollary to a witness' duty to testify and produce tangible evidence is the government's obligation to minimize the burden on the individual of testifying. ${ }^{212}$ The fact that a search imposes more of a burden by intruding more drastically on the citizen's privacy than a subpoena argues for less emphasis in the search situation on the citizen's testimonial duty. Indeed, while the maxim that the court is entitled to every person's testimony continues to be

rooms or floors, or several buildings simultaneously." Id. at Ior. By far most searches accompany arrest rather than proceed by search warrants. Id. at I05. Yet whatever the importance to criminal investigation of searches incident to arrest in general, they are virtually irrelevant to the press searches under consideration here because normally no one associated with the press facility is implicated in crime. Other legal alternatives to a search pursuant to a warrant, including the consent search, search of vehicles, search of state-licensed premises, border searches, and stop-and-frisk are also irrelevant in the press search situation. See Amsterdam, stipra note 16 , at 358-60.

203. Detection of Crime, supra note 97, at 3-4; E. Eldefonso, A. Coffey \& J. Sullivan,

Police and the CRiminal LaW 62 (I972).

204. See note 3 supra; notes $97-98$ supra and accompanying text.

205. See notes $158-6 \mathrm{I}$ supra and accompanying text.

206. See, e.g., CaL. Penal Code $\S 135$, I52.

207. See, e.g., Bethview Amusement Corp. v. Cahn, 4I6 F.2d 4IO (2d Cir. I969); Stanford

Daily v. Zurcher, 353 F. Supp. 124, 133 (N.D. Cal. 1972), appeal docketed, No. 74-3212, 9th Cir.,

Nov. 20, 1974.

208. See 86 HaRv. L. REv. I3I7, I330-3I (I973).

209. 408 U.S. at 688.

210. See notes 99-I00 supra and accompanying text.

2II. See note 5 I supra and accompanying text.

2I2. See note ro2 supra and accompanying text. 
a favored rationale for curtailing claims of testimonial privilege, a contrary impulse has characterized the judicial treatment of search and seizure. ${ }^{213}$

\section{Conclusion: A New Balancing of Interests}

Composed of neutral citizens, the grand jury acts in a deliberative environment under judicial supervision. Reporters, like other witnesses, may enlist the court's supervisory assistance to forestall the grand jury's undue interference with press interests. By threatening recourse to the courts, the witness may force the grand jury into reassessing the evidentiary value to it of the journalist's testimony, even if a formal judicial balance would not favor the reporter. When the balance does tip for the journalist, his interests are protected before the government body invades them. And even when forced to testify, the reporter can encourage continued source confidence with promises not to reveal information or to reveal as little as possible.

Search and seizure, on the other hand, has no procedural mechanism that guarantees as full a consideration of the interests involved before action is taken. The probable cause requirement may make it somewhat more difficult to obtain a warrant than to activate a subpoena, although even this proposition is doubtful given magisterial reliance upon police affidavits. Nevertheless, once the warrant is issued, nothing can restrain its operation until it has overrun whatever press interests stand in its way. If the search proves legal, the victim has no way to remedy or ameliorate the damage to press interests-interests that the magistrate and police never consider when authorizing and executing the search. If the search proves to be illegal, the victim, especially if not implicated in crime, has inadequate remedies for the vast damage searches cause to the operation of a press facility and its newsgathering activities.

Cases since Branzburg have determined that the balance of press and government interests in that decision was close; only in instances "few in number to be sure" must threatened first amendment values yield. ${ }^{214}$ The preceding analysis indicates that Branzburg's delicate balance in favor of government interests does not control the search question. Branzburg deals only with the "uncertain" effect on newsgathering of the refusal of the viewer of a crime even to appear to testify. On the other hand, searches usually are resorted to when evidence sought is second hand and tangible, rather than eyewitness and testimonial. Moreover, the constant threat of a search affects editing and dissemination and clearly inhibits the press' newsgathering functions prior to any demand that a reporter testify. These circum-

213. Compare $8 \mathrm{~J}$. Wigmore, supra note 28, at $\$ 2$ I92, with Mapp v. Ohio, 367 U.S. 643 (196x). $(1973)$.

214. Baker v. F \& F Investment, 470 F.2d 778, 783 (2d Cir. 1972), cert. denied, 409 U.S. 966 
stances dictate greater press protection from searches than may be appropriate in the case of subpoenas.

In addition, since a search warrant permits executive law enforcement officials to trample the first amendment interests at stake before the press has a chance to plead its case, it is entirely inconsistent with the procedural fastidiousness upon which the Court usually insists in first amendment situations and that it found in Branzburg in the case of press subpoenas. And searches not only inhibit a wider array of first amendment interests, they also involve graver infringements of reporters' fourth amendment privacy interests. ${ }^{215}$

Finally, the government interests pulling in the opposite direction are clearly less vital than in the subpoena situation. In most, if not all, cases the grand jury subpoena serves a much more significant societal role in the prosecution of crime than does search and seizure. The former, additionally, is perhaps the most important instance in which the duty of every person to produce available evidence is applied to protect the integrity of society's dispute-solving mechanism. That duty is virtually irrevelant in the search and seizure situation.

Branzburg $v$. Hayes ${ }^{216}$ does not settle the constitutionality of press searches. In fact, the comparison of interests in that case with the governmental and press interests affected by search and seizure of media illustrates the need for different standards than those laid down in Branzburg to protect newsrooms from these more drastic police intrusions. It is to a discussion of those new standards that the next section is devoted.

\section{A New Rule for Media SeArches}

Since both privacy and free press interests are at stake in media searches, two doctrinal approaches are available for assuring needed protection-one based on the fourth amendment and the other on the first amendment. Each approach is encumbered by a package of troubling questions.

215. The courts have recognized the search's comparative potential for violence to individual privacy interests on the one hand, and the subpoena's potential for judicial protection on the other, when deciding whether and how to extend fourth amendment protection to subpoenas. In the face of the practical, procedural and judicial restraints on subpoenas, the Supreme Court in Hale $v$. Henkel, 201 U.S. 43 (1906), applied weak fourth amendment protections to certain uses of the subpoena. See notes $151-52$ supra and accompanying text. One concurring Justice argued that even those are unnecessary given the high degree of intrusiveness that the fourth amendment permits in "reasonable" searches and seizures. Id. at 80-8I (McKenna, J., concurring); see United States v. Dionisio, 4I0 U.S. I, ro-I2 (1973); People v. Warburton, 7 Cal. App. 3d 815, 86 Cal. Rptr. 894 (2d Dist. I970) (described in note I 82 supra).

2I6. 408 U.S. 665 (1972). This analysis suggests that replacement of the subpoena with the search warrant should change the balance struck in Branzburg by Justice White. Yet Justice White's opinion may not be the law even as to the circumstances involved in Branzburg. The "controlling" Powell concurrence, as interpreted in subsequent lower and state court adjudication, suggests standards 


\section{A. A Fourth Amendment Approach}

Confronted with a challenge to the legality of a police search of a university newspaper, Judge Peckham in Stanford Daily v. Zurcher ${ }^{217}$ found considerable protection from press searches in the fourth amendment's proscription against unreasonable searches and seizures. ${ }^{218}$ This case held for the first time that availability of the less intrusive subpoena makes unreasonable the government's alternative use of a search to obtain evidence in the hands of persons not implicated in crime. The fact that those persons were also members of the press was not essential to this holding.

The standards Judge Peckham set countenanced such "third party" searches only when a subpoena is "impractical."219 In so doing, Judge Peckham suggested that the fourth amendment has always implicitly recognized the differential impact of search and subpoena and has justified the use of searches under the traditional probable cause standards-that is, probable cause to believe that the item sought is in the specified location and that it is related to the specified crime-only when there is a nexus to the crime of the item's owner. Absent that nexus, the court held, a new probable cause standard applies. While Judge Peckham's conclusion that parties not implicated in crime deserve special protection from searches has intuitive appeal, each aspect of his fourth amendment rationale poses problems. ${ }^{220}$

Judge Peckham justifies greater safeguards for victims of third party searches by analogizing to the special protections accorded to arrested witnesses under the Federal Rules of Criminal Procedure. ${ }^{221}$ However, the rules regarding arrest of material witnesses not only have questionable constitutional mandate, ${ }^{222}$ but they are also improperly analogized to the search

more protective of newspersons and especially incapable of accommodation by the search warrant process. See notes I09-14 \& 122 supra and accompanying texts.

217. Stanford Daily v. Zurcher, 353 F. Supp. r24, I27 (N.D. Cal. 1972), appeal docketed, No. 74-3212, 9th Cir., Nov. 20, 1974. See 86 HARv. L. REv. 13I7, 1319-23 (I973) for a critique of this portion of the decision.

2I8. U.S. CoNsT. amend. IV.

219. 353 F. Supp. at 127, 132. While this test did not depend upon the identity of the third party, Judge Peckham added a somewhat more difficult test for issuing press search warrants requiring proof that destruction is imminent and a restraining order useless. Id. at I35.

220. Note that no court in California, the only state where a criminal defendant may suppress evidence illegally seized from a third party, has ever suggested that a nonsuspect search is automatically illegal.

22I. FED. R. CRM. P. 46 (b).

222. Compare Bacon v. United States, 449 F.2d 933 (9th Cir. I97I) (implying a fourth amendment basis for federal statutory protection of incarcerated witnesses), with United States ex rel. Gibbs $\nabla$. Zelker, 496 F.2d 99 I (2d Cir. I974) (leaving undecided whether the fourth amendment requires the federal witness incarceration rules) and 86 HARv. L. REv. I3I7, I3I9-20 (I973) (arguing against a constitutional basis for $46(\mathrm{~b})$ ). See also Barry v. United States ex rel. Cunningham, 279 U.S. 597, 618 (1929) setting an apparently lesser constitutional standard ("suspicion") than rule 46(b)'s standard ("probable cause") as to witness" probable fight, for legal incarceration of a witness. If the standards set in the federal statutes are constitutionally mandated and apply to the states, the procedures for dealing with third party arrestees in all states are probably unconstitutional. See Carlson, Jailing the Innocent: The Plight of the Material Witness, 55 Iowa L. REv. I (1969). 
and seizure context ${ }^{223}$ because constitutional law traditionally has not equated the criteria for permissible searches with those for arrests. ${ }^{224}$

Furthermore, the identity of the owner of the evidence historically has not determined the availability of search warrants. ${ }^{225}$ Rather, probable cause to believe that material related to criminal activity is on the premises (perhaps unknown to its owner) suffices to allow police entrance by warrant. ${ }^{226}$ Nor is a search of the premises occupied by persons implicated in crime less intrusive than a third party search. It might be argued that at least suspected possessors of stolen or illegal property have a lesser expectation of privacy concerning it, since they have no legal claim to ownership. Nonetheless, the failure of established constitutional doctrines to distinguish between searches of suspects' and nonsuspects' premises is sound. It acknowledges that the privacy interests of individuals should not rise or fall according to the allegations of police. From one viewpoint it may say that nonsuspects are given no greater protection than suspects, but from the other side it asserts that even alleged wrongdoers are guaranteed all the rights of other citizens until proven guilty. This premise is too central to our judicial tradition to allow room for varying levels of privacy rights based on allegations of criminality, no matter how intuitively appealing that notion may be. ${ }^{22 \pi}$

223. The fourth amendment provides different protections for victims of arrests and searches. Judge Peckham notes, however, that with respect to suspects, the arrest standards are generally less stringent than those protecting search victims and argues from there that the arrest requirements for nonsuspect, material witnesses should at least form the baseline for third party searches. $353 \mathrm{~F}$. Supp. at 130. But this conclusion does not necessarily follow. The standards for arrest of persons suspected of crime must be understood in light of the other protections available to the suspect, e.g., the right of counsel and the right to withhold evidence by remaining silent. Aggregating all of the protections in the Bill of Rights, the arrested suspect receives much greater constitutional protection than the search victim. Furthermore, the non-fourth amendment protections are inoperative in the case of the incarcerated nonsuspect. For example, such an arrestee does not have the right to an attorney or to a statement of the right to remain silent, even though such "witnesses" are often held until sufficient evidence accumulates to charge them with a crime. See Carlson, supra note 222; $c$. United States ex rel. Gibbs v. Zelker, 496 F.2d 99I (2d Cir. 1974). Arguably, therefore, the federal law merely substitutes statutory protection of nonsuspects at the stage of arrest for the unavailable fifth and sixth amendment protections of arrested suspects. There is no evidence that the Constitution compels this compensatory protection. But even assuming otherwise, the third party search victim may not warrant similar compensatory protection since he already enjoys as much protection from unreasonable searches as does the suspect whose premises are searched (except for the exclusionary rule, which Judge Peckham's test still denies to the victims of third party searches).

224. See 86 Harv. L. Rev. I3I7, I320-2I (I973).

225. See United States v. McClard, 333 F. Supp. 158 (E.D. Ark. r97I) (search valid, though search warrant did not name the owner of the searched premises); 86 HARV. L. REV. I3I7, I320-2I. 226. Warden v. Hayden, 387 U.S. 294, 307 ( 1967$)$ : The law merely requires a "nexus . . . between the item to be seized and criminal behavior," that is, "probable cause . . . to believe that the evidence sought will aid in a particular apprehension or conviction." This requires no more than "consideration of police purposes."

227. The contours of Judge Peckham's test are also problematic. For example, he never defines a third party. To carry out a search, must there be probable cause to believe not only that criminal evidence exists on certain premises, but also that its owner (occupier, possessor, or a trespasser?) committed a (particular?) crime? Or would mere suspicion suffice? If the former test applies, Judge Peckham has succeeded in making a three-part probable cause standard (relationship of items to crime, location of item, and criminality of item's possessor) out of what has always been a two-part probable cause test (nexus of object to crime and location of object), i.e., in making every search warrant also an arrest warrant. Traditionally, however, courts have insisted that at least the past 
Judge Peckham's most persuasive argument follows a "less drastic alternatives" rationale, ${ }^{228}$ applied to the fourth amendment apparently for the first time. Because there exists a well-established, traditionally favored evidence-gathering alternative-the subpoena - the least restrictive alternatives doctrine avoids a common pitfall when striking a procedure for not being the least restrictive one possible: the courts' need to legislate the better alternative. ${ }^{220}$ Nonetheless, this theory too seems troublesome. First, the constitutional vitality of the least restrictive alternatives test may be in doubt. ${ }^{230}$ Moreover, a subpoena is always less drastic than a search, yet Judge Peckham does not explain why only nonsuspect third parties should have the protection of this less intrusive procedure. $\mathrm{He}$ may be assuming that a criminal suspect is more likely than a third party to destroy evidence, necessitating a search and seizure. Not only is this rationale based on a questionable behavioral assumption; in addition it increases the importance of proving the probable nexus of the owner to criminal activity before ever obtaining a warrant and the problems attendant upon doing so. ${ }^{231}$ These factors illustrate the difficulties in extending the less restrictive alternatives test to any criminal procedure.

Although Judge Peckham premised his elevated fourth amendment standard primarily on the nonsuspect status of the search victim, he also bolstered that argument with reference to Stanford Daily's status as a newspaper ${ }^{232}$ Just as the fourth amendment recognizes especially intense privacy interests surrounding the home and particularly the bedroom because of other fundamental rights centered there, ${ }^{233}$ it arguably should provide special protection from governmental intrusion for those places where other fundamental freedoms-such as freedom of the press-normally reside. This approach would avoid the troubling distinction between privacy rights

or reputed criminality of the possessor is irrelevant to the determination of a search warrant's propriety. See Aguilar v. Texas, 378 U.S. I08 (I964). If mere suspicion of having committed a crime suffices, Judge Peckham's rule adds little to the old probable cause test since most possessors of criminal items, without more, are suspect.

228. 353 F. Supp. at I30.

229. See Gunther, Reflections on Robel: It's Not What the Court Did But the Way that It Did It, 20 STAN. L. REV. II 40, II47-48 (I968); 86 HARV. L. REV. 13I7, I32I-23 (I973).

230. In the past, only first amendment interests have benefited from the requirement of the least oppressive alternative. Justice White in Branzburg even refused to extend the analysis from those first amendment cases in which it has applied in the past to new first amendment situations, suggesting a retreat from the doctrine. 408 U.S. at 680-81, 699-700; see Murasky, supra note 27, at 875 .

23x. It may be difficult to link specific persons to specific crimes in the early stages of an investigation and without first seizing evidence of criminal activity. $C f$. Branzburg v. Hayes, 408 U.S. $665,701-02$ (I972). Otherwise the search warrant would be a redundancy given the legality of and police preference for the arrest warrant. See note 202 supra.

232. 353 F. Supp. at $133-35$. See note 219 supra.

233. See Griswold v. Connecticut, 38r U.S. 479 (1965) (marital bedroom). Compare Stanley v. Georgia, 394 U.S. 557 ( 1969 ) (certain obscenity laws invalid when enforced [in this case, using search and seizure] against possession of obscene material solely in the home), with United States v. Orito, 4I3 U.S. I39 (I973) (valid to apply a similar federal law to transportation of similar obscene material from one home to another). 
of suspects and nonsuspects at the heart of Judge Peckham's special rule for third party searches. But it still would involve a troubling new doctrine in fourth amendment common law: the notion that the fourth amendment offers multiple-tiered protections depending on the character of the search victim. ${ }^{284}$ Before embracing a concept with such far-reaching implications, courts should consider whether an analysis based on established first amendment doctrines, rather than on this new view of the fourth amendment, will not offer sufficient protection for the press.

\section{B. A First Amendment Approach}

\section{Defining the extent of protection.}

Judge Peckham's approach may be criticized for introducing into fourth amendment doctrine two potentially upsetting new elements-least restrictive alternative analysis and multiple-level protection based on the search victim's nonsuspect status. However, the rule he announced to regulate searches of media can be based on established first amendment doctrine without muddying the waters of fourth amendment theory. Thus, instead of stressing the special privacy interests of nonsuspect third parties, courts might consider the special first amendment interests of newsgathering, editing, and dissemination. Similarly, whereas least restrictive alternative analysis is alien to fourth amendment theory, it frequently has been enlisted in first amendment cases. ${ }^{235}$ Assuming for the moment that a first amendment analysis can support Judge Peckham's rule, one still should consider whether it assures the press adequate and properly fitting protection from police searches.

Judge Peckham's rule would authorize magistrates to issue warrants for searches of the press upon a clear showing of the imminent destruction of crucial evidence and of the futility of a restraining order to prevent that destruction. ${ }^{236}$ Given the ex parte nature of warrant applications ${ }^{237}$ and the deference traditionally given police requests, ${ }^{238}$ there is considerable risk even under this tough standard that press searches will be abused, especially since this test still makes damage actions for improper searches difficult to win. ${ }^{239}$ Since other remedies are ineffectual, ${ }^{240}$ courts faced with this possi-

234. The Supreme Court has afforded certain intimate localities greater fourth amendment protection, see cases cited supra note 233 , because expectations of privacy there are greater than elsewhere. This rationale rests those decisions on traditional fourth amendment doctrine, see note $8 \mathrm{I}$ supra and accompanying text, rather than on untried notions regarding the character of the owners of searched premises.

235. But cf. note 230 supra; notes $248-49$ infra and accompanying text.

236. 353 F. Supp. at 135 .

237. See notes $173 \rightarrow 74$ supra and accompanying text.

238. See notes $169-74$ supra and accompanying text.

239. See note 183 supra and accompanying text.

240. See note $180-83$ supra and accompanying text. 
bility may decide that the general threat to first amendment values outweighs the general state interest in obtaining those items of evidence alleged to be in danger of destruction by the media, and that this balance of interests justifies a per se rule forcing police to secure evidence from the press by subpoenas, never by searches.

In support of this conclusion, it can be argued that if a newspaper in fact would prefer to destroy evidence and face criminal charges or contempt rather than comply with a subpoena, it also probably would take precautions against having that evidence seized by a surprise search. ${ }^{241}$ If so, a police raid would be far more likely to harm legitimate press functions and harass the newspaper staff than it would be to net the evidence sought. Moreover, this per se rule would avoid introducing novel standards into traditional search and seizure proceedings and make the magistrate's authorization and police officer's execution of a warrant so clearly illegal as to remove good faith defenses in suits against the officials for illegal searches.

Although the "imminent destruction of evidence" test proposed by Judge Peckham may not withstand careful scrutiny, there is one exception to the no-search rule that seems necessary. If media premises are rendered immune from police entry, it is possible that persons engaged in crime will try to conceal evidence by handing it over to sympathetic members of the press. ${ }^{242}$ This risk could be alleviated by permitting third party media searches only on a showing of probable cause to believe that specified instrumentalities of crime or contraband will be found on the premises. The standard draws a clear line that is familiar to magistrates ${ }^{243}$ and rests on established first amendment principles; ${ }^{244}$ rarely will a source-or an issuing

241. See notes 70 \& I 42 supra and accompanying texts.

242. What, for example, if a member of the "Symbionese Liberation Army" had turned over to the press the alleged Marcus Foster murder weapon, rather than merely a letter taking credit for that slaying? See note 3 supra.

243. Until 1967 , the fourth amendment only allowed searches for contraband or instrumentalities; "mere" circumstantial evidence was immunized. Warden v. Hayden, 387 U.S. 294 (I967), abolished the mere evidence rule generally, although it has since been resurrected in selected circumstances. See, e.g., Coolidge v. New Hampshire, 403 U.S. 443 (I97r), which laid down a rule illegalizing the seizure of any anticipated items not named in a warrant but found in "plain view" during an otherwise legal search, unless the items are "contraband [or] stolen goods [or] dangerous in themselve:" Id. at $47 I$.

244. In a I 973 obscenity search and seizure case, Roaden v. Kentucky, 4I3 U.S. 496 (r973), the Supreme Court noted: "The seizure of instruments of a crime, such as a pistol or a knife, or "contraband or stolen goods or objects dangerous in themselves' ... are to be distinguished from quantities of books and movie films when a court appraises the reasonableness of the seizure under Fourth or Fourteenth Amendment standards." Id. at 502, quoting Coolidge v. New Hampshire, 403 U.S. 443, 47 I (r973). Roaden is one of a long line of cases, see, e.g., Heller v. New York, 4r3 U.S. 483 (1973) and A Quantity of Books v. Kansas, 378 U.S. 205 (I964), that find in first amendment "due process," see note I65 supra, a requirement that searches of movie houses and bookstores for allegedly pornographic material must be preceded or closely followed by adversarial adjudication of the question of the material's illegality. In the passage quoted, Roaden excepted from that rule any search of a movie house or bookstore involving the seizure of contraband and criminal instrumentalities. Coolidge and Roaden suggest that at the margin of permissible searches society's interest in obtaining contraband or criminal instrumentalities tips the balance in favor of seizure. On the other 
magistrate-not know if an item is contraband, stolen or an instrument of crime. Therefore, immunity from search, while qualified, will have minimal dampening effects on sources. And the test's clear line will enable magistrates to withhold warrants in most cases where legally required: illegal searches generally would have to be warrantless and subject to damages suits more immune from good faith defenses. This test has the virtue of allowing police access to items that actually contributed to criminal activity, for example, a murder weapon, while immunizing from search and seizure items whose sole purpose is to inform, for instance, a letter explaining a slaying. To assure fuller protection, the rule could be coupled with a prohibition against police authorization to seize unspecified, additional evidence during the course of the search. ${ }^{245}$

\section{Selecting a doctrinal approach.}

A court reaching this balance of interests would have two analytical approaches for doing so. The first is the traditional "compelling state interest" test; the second is more explicit balancing.

The traditional test. Although Branzburg used the traditional approach to uphold the government's subpoena of reporters against their claims of first amendment privilege, ${ }^{246}$ that case does not necessarily control a similar analysis of searches. As demonstrated in Part II, additional press interests are jeopardized by searches of the media, and the intrusion on those interests is also more severe than with the subpoena procedure. Thus, the government interests found compelling in Branzburg arguably are not overriding in the search context. It is not clear, however, that the traditional test (which claims to eschew balancing) takes account of varying levels of first amendment interests. ${ }^{247}$ If not, then a state interest found compelling in one case would seem to override all first amendment claims in future cases.

Even when the state's goals are found compelling, however, some first amendment cases have required the government to use the least restrictive means to reach those goals. Under this doctrine, courts could still require police to use subpoenas as a less intrusive means of securing media-held

hand, the balance tips against the seizure of less important, circumstantial evidence. This principle holds true although the victim of either search has the same privacy interest.

245. Such a rule would be an exception to the traditional rule that police may seize unanticipated items in "plain view" relating to criminal activity. See Coolidge v. New Hampshire, 403 U.S. $443,464-72$ (I $97 x$ ).

246. Branzburg v. Hayes, 408 U.S. $665,700-0$ I (I972).

247. Actually, Justice White's approach in Branzburg may resemble balancing more than the "compelling state interest" approach. While devoting only two brief passages to the latter doctrine, 408 U.S. at $680-8 \mathrm{I}$, 700-0I, Justice White discusses at great length the "important role" of the grand jury in criminal investigation, $i d$. at 687 , and the "essential" support provided that body by the subpoena, $i d$. at 688 . To this is compared the "consequential, but uncertain" effect of grand jury subpoenas, $i d$. at $690-9 x$, on constitutionally protected newsgathering. Id. at 707. Justice White's conclusion is that "the public interest in law enforcement" is sufficient "to override" the negative press effects. Id. at $690-91$. 
evidence, even while recognizing a compelling state interest in finally acquiring that evidence. However, two snags flaw this reasoning. First, where no viable alternative exists, search warrants would have to be permitted in order to effectuate the state's purpose. Thus, police might be able to seek warrants upon a showing of imminent destruction of evidence or the reporter's announced vow to resist subpoenas. At any rate, the uncertainty engendered by this "no alternative" loophole would invite test searches at least initially, and perhaps for some time, injurious to first amendment values.

Second, Justice White in Branzburg explicitly ruled out reliance on "least restrictive alternative" analysis in the subpoena context ${ }^{248}$ because he felt it invites "legislative" decisionmaking. ${ }^{249}$ In reply, it can be argued that Justice White erred in holding this analysis inapplicable. ${ }^{250}$ Alternatively, one might try to distinguish Branzburg on the ground that subpoenas would require novel alternatives, whereas search warrants have an existing alternative-the subpoena itself.

Balancing. The web of difficulties inhering in the traditional, two-tiered analysis is avoided by a more flexible balancing approach. Balancing permits the court to weigh the different intensities of first amendment interests in the subpoena and search situations, rather than being bound by a prior determination that the state's interest is compelling and therefore forever overriding. Moreover, it supports scrutiny of feasible alternatives in the context of weighing the intensity of the government's interests in securing evidence. For example, a court might find the government's need for information is the stronger interest where no alternatives to a search are available, but not otherwise.

The major criticism levelled against balancing is that it spawns ad hoc decisionmaking based on the judges' personal values. While the traditional test may be rigid, its supporters argue that at least it avoids the slippery slope of subjective adjudication. However, Justice Powell's use of balancing proves that principled adjudications are feasible. ${ }^{251}$ Over time, he has found it increasingly possible to generalize the components of his first amendment balancing and in this way terrace the adjudicative slope so that other judges might follow his steps more easily.

Such adjudication by comparison of competing interests seems most workable in the press search context given the nearly equal intuitive

248. $1 d$. at $699-700$.

249. Id. at 705-06.

250. See Murasky, supra note 27 , at $875-76$.

25I. See Gunther, stipra note III. Compare Saxbe v. Washington Post Co., 4 I7 U.S. 843, 850-75 (I974) (Powell, J., dissenting), with Branzburg v. Hayes, 408 U.S. 665, 709-Io (I972) (Powell, J., concurring). 
strengths of the four interests involved. Proceeding from the assumption that the decision in Branzburg can be justified as the result of balancing, ${ }^{252}$ this approach would justify greater press protections in the search situation than that case required with subpoenas: compared to subpoenas, searches more severely inhibit more first amendment and privacy interests, despite searches' uncertain accomplishment of any governmental goals not served by subpoenas. These differences should suffice to tip in the opposite direction the close balance struck in Branzburg. ${ }^{253}$

\section{Conclusion}

After journalists failed to secure complete protection from subpoenas in Branzburg, they turned their attention to thus far unavailing attempts at federal shield legislation. ${ }^{254}$ The press has been more successful in advancing their interests in state legislatures and lower federal and state courts. In fact, the effectiveness of state shield legislation and of the holdings of state and lower federal courts in blocking enforcement of press subpoenas probably motivated the development of a new government means of acquiring information-the press search.

Nonetheless, the media may look to the same fora that have partially shielded them from subpoenas for perhaps more complete protection from searches. The 26 state shield laws, particularly if extended to other and strengthened in all jurisdictions, offer a framework for sheltering the press from searches, despite troublesome gaps in their language and jurisdictional applicability, as well as in their availability prior to police intrusion. More general constitutional protection is also available. 'The courts' willingness to read Branzburg to immunize reporters from some subpoenas indicates their likely receptiveness to even greater press immunity from searches, because searches exaggerate the negative first amendment effects discussed in Branzburg without a concomitant boost to governmental interests. Either traditional "compelling state interest" doctrine or a balancing approach more explicit justify the courts in achieving various degrees of protection from media searches-including a per se ban as well as standards limiting searches to certain journalists (for example, ones likely to destroy evidence) or to certain kinds of evidence (for example, contraband and criminal instrumentalities).

In addition to illustrating the potential for, and pitfalls in, various statutory and constitutional routes to control media searches, the preceding analysis also suggests the virtue of press reliance for protection on the fluid scene 
presented by state legislatures and state and lower federal courts. While failure has marked efforts at federal legislation, and journalists' "gloom" greeted the Supreme Court's decision in Branzburg, ${ }^{255}$ the trend has been toward greater protection in more local legislative and judicial arenas. The multiplicity of potential press protective theories and fora in which to advance them allows the various voices of the press to advance their own, sometimes inconsistent, needs on several different fronts. Not only does this multifaceted approach give all aspects of the media more significant input into the law's development; in addition it makes each state legislature and each state and lower federal court a laboratory in which "to remould, through experimentation," ${ }^{268}$ the law and to better accommodate the competing informational claims of the press, law enforcement officials and, ultimately, the public.

James S. Liebman

255. See Goodale, supra note 27 at I33.

256. New State Ice Co. v. Liebmann, 285 U.S. 262, $3 x x$ (x932) (Brandeis, J., dissenting). 